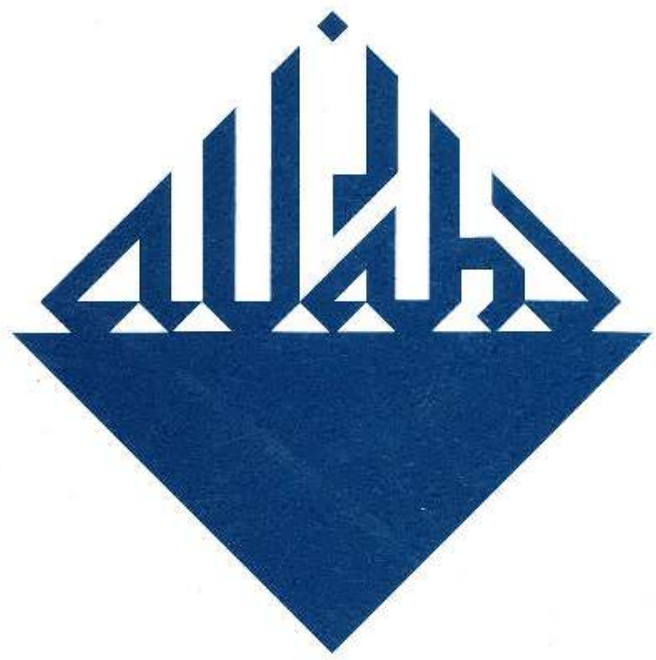

ANTI-AMERICANISM

IN CONTEMPORARY INDONESIA

Saiful Mujani

Javanese Stories of Jesus

Alef Theria Wasim \&

Karel Steenbrink

CirCumlocutory IMPERIALISM:

WATAN IN THE THOUGHTS

of Syed Shaikh bin Ahmad al-Hady

Ismail F. Alatas 


\section{STIDIIA ISLAMIIKA}

Indonesian Joumal for Islamic Studies

Vol. 12, no. 2, 2005

EDITORIAL BOARD:

M. Quraish Shihab (UIN Jakarta)

Taufik Abdullah (LIPI Jakarta)

Nur $\Lambda$. Fadhil Lubis (IAIN Sumatra Utara)

M.C. Ricklefs (Melbourne University)

Martin van Bruinessen (Utrecht University)

John R. Bowen (Washington University, St. Louis)

M. Atho Mudzhar (IAIN Yogyakarta)

M. Kamal Hasan (International Islamic University, Kuala Lumpur)

EDITOR-IN-CHIEF

Azyumardi Azra

EDITORS

Saiful Mujani

Jamhari

Jajat Burhanuddin

Fu'ad Jabali

Oman Fathurahman

ASSISTANT TO THE EDITORS

Heni Nuroni

ENGLISH LANGUAGE ADVISOR

Cheyne Scott

ARABIC LANGUAGE ADVISOR

Muhbib Abdul Wahab

COVER DESIGNER

S. Prinka

STUDIA ISLAMIKA (ISSN 0215-0492) is a journal published by the Center for the Study of Islam and Society (PPIM) UIN Syarif Hidayatullah, Jakarta (STT DEPPEN No. 129/SK/DITJEN/PPG/STT/1976) and sponsored by the Australia-Indonesia Institute (AII). It specializes in Indonesian Islamic studies in particular, and South-east Asian Islamic Studies in general, and is intended to communicate original researches and current issues on the subject. This journal warmly welcomes contributions from scholars of related disciplines.

All articles published do not necessarily represent the views of the journal, or other institutions to which it is affiliated. They are solely the views of the authors. The articles contained in this journal have been refereed by the Board of Editors.

STUDIA ISLAMIKA has been accredited by The Ministry of National Education, Republic of Indonesia as an academic journal (SK Dirjen Dikti No. 23a/DIKTI/2004). 


\section{Ismail F. Alatas}

\section{Circumlocutory Imperialism: Watan in the Thoughts of Syed Shaikh bin Ahmad al-Hady*}

Abstraksi: Tulisan ini membahas pemikiran Syed Syaikh bin Ahmad alHady (1867-1934) tentang konsep watan (tanah air). Pemikiran ini penting dalam konteks perubahan sosial politik Malaysia yang pada mulanya menganut sistcm kerajaan yang tradisional, setelah mordeka dari Inggris pada 1957 menjadi scbuah negara bangsa (nation-state). Al-Hady beranggapan bahwa konsep kerajaan yang bertumpu pada sosok raja — di mana raja tidak saja memiliki kekuasaan politik atas sebuah wilayah yang disebut nagari, namun juga memiliki pengaruh spiritual - tidak dapat menampung identitas ke-Mclayu-an yang modern. Karena itu kemudian, untuk mengatasi hal ini, ia mengajukan konsep wațan, scbuah konsep yang pada mulanya berkembang di Eropa yang mengharuskan adanya sekularisasi, baik dalam wacana maupun praktik.

Menariknya adalah, al-Hady meramu konsep ini lewat scjumlah pemikiran mushim modern di antaranya Muhammad 'Abduh dan Jamāl al-Din alAfgānin, dua tokoh modemis muslim yang banyak mempengaruhi pemikirannya. Sepcrti diketahui, pada akhir abad ke-19 gagasan nasionalisme yang pada mulanya muncul di Eropa melanda negeri-negeri muslim termasuk Malaysia sepcrti tereficksikan dalam pemikiran al-Hady. Al-Hady tentu mengenal bctul gagasan ini lewat kehidupan intelektual dan sosialnya yang sangat luas scjak masa mudanya. Pada akhir abad ke-19, atas bantuan Kesultanan Riau, ia dikirim ke Kairo. Di sinilah ia kemudian berkenalan dengan gagasan-gagasan 'Abduh dan al-A fgānī.

Sejak awal al-Hady menunjukkan ketcrtarikan dengan gagasan-gagasan pemikir modernisme Islam. Setelah menyelesaikan pendidikannya di Me- 
sir, ia kcmbali ke Malaysia dan sclanjutnya tinggal di Singapura. Di sini, bersama dengan Syaikh Tahir Jalaluddin, yang juga alumni Kairo, ia menerbitkan al-Imam, sebuah jurnal yang banyak menyuarakan gagasan-gagasan modernisme Islam di Malaysia dan juga Indonesia. Di samping itu ia juga mendirikan sebuah lembaga pendidikan yang diberi nama al-Iqbal.

Pada 1913, Belanda membubarkan Kesultanan Riau. Peristiwa ini menjadi titik balik penting dalam pemikiran al-Hady. Bagaimana tidak, baik alImam maupun al-Iqbal keduanya mendapat sokongan dana dari kesultanan. Sejak pembubaran ini, ia mengalami kesulitan finansial untuk monghidupi jurnal dan sekolahnya tersebut. Dan yang lebih penting lagi, peristiwa ini memberi pelajaran penting baginya bahwa sistem kerajaaan sangat rapuh dalam menghadapi kolonialisme Eropa. Karena itu kemudian ia berupaya untuk mencari konsep baru sebagai pengganti konsep kerajaan. Pada saat itulah konsep watan yang sudah lama ia kenal dianggap dapat menjadi wacana alternatif.

Akan tetapi tidaklah mudah merekonstruksi konsep wațan al-Hady. Gagasan yang dilahirkan pada era kolonialisme pada umumnya, seperti dikatakan oleh Homi Bhabha, "penuh dengan kontradiksi wacana kolonial." Demikian pula dengan pemikiran al-Hady. Pada satu sisi, ia memuji penguasa kolonial Inggris sebagai pembcbas bangsa Mclayu dari kebodohan dan keterbelakangan, serta mencerca para raja dan pangeran sebagai penguasa lalim yang mengajarkan takhayul dan khurafat kepada masyarakat. Namun pada sisi lain, ia juga mengkritik kekuasaan Inggris di Malaya. Dalam berbagai tulisannya, al-Hady mencoba menyadarkan bangsa Melayu agar tidak bertekuk lutut kepada penjajah.

Salah satu hal yang senantiasa ditekankan olch al-Hady dalam berbagai tulisannya adalah agar bangsa Mclayu bekerja keras. Bahkan tidak bcrlcbihan untuk mengatakan bahwa gagasan ekonomi al-Hady sangat kapitalistik. Scbaliknya ia mengkritik feodalisme kcrajaan yang pada akhirnya membuat orang malas. Dari sini kemudian muncul 'mitos pribumi malas' yang sengaja diciptakan penjajah. Sistem feodalistiklah yang membuat mereka tidak berpartisipasi dalam kcgiatan ckonomi ketika negeri tersebut mengalami peralihan sistem ekonomi yang tradisional ke kapitalisme. Abscnnya mereka ini lalu diisi oleh masyarakat Cina yang pada awal abad ke-20 banyak bermigrasi ke sana.

Dari sekian kontradiksi yang ada, ada satu hal yang membuat gagasan wațan al-Hady terdengar begitu bergaung. Jauh sebelum Malaysia memproklamirkan kemerdckaannya, bebcrapa dasawarsa sebclumnya al-Hady secara jelas mengatakan bahwa negara Melayu merupakan kesatuan sosial, politik dan budaya bangsa Mclayu yang meliputi scluruh wilayah di Semenanjung Malaysia. 
Ismail F. Alatas

Circumlocutory Imperialism:

Watan in the Thoughts of

Syed Shaikh bin Ahmad al-Hady*

خلاصة: هذا المقال يتاول بحثا في فكر سيد شيخ بن بن أحمد المادي

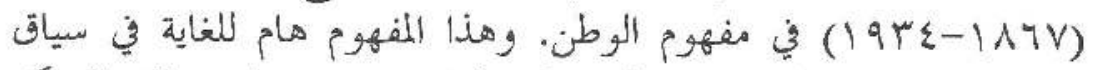

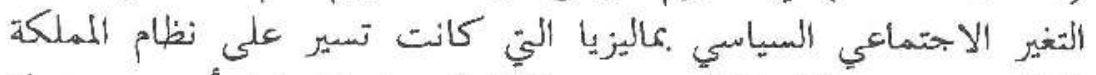

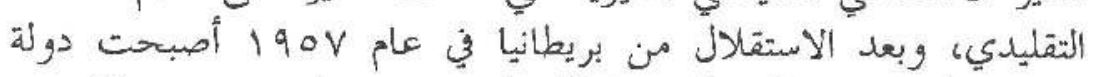

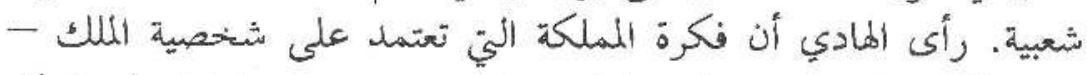

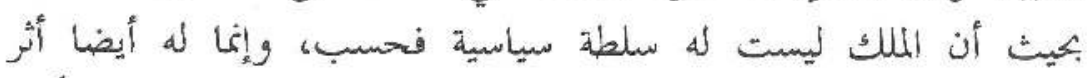

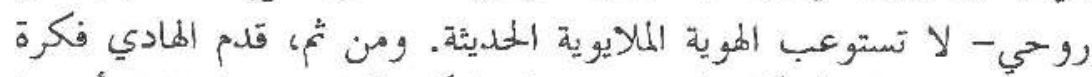

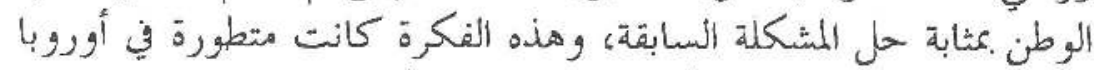

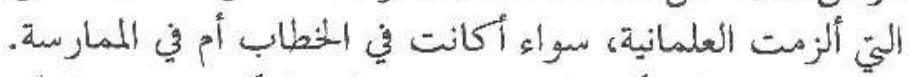

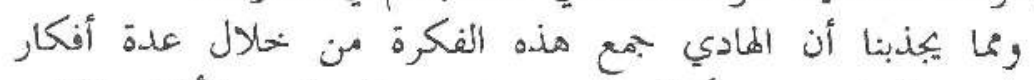

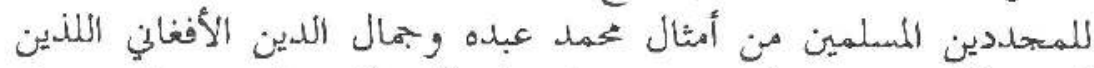

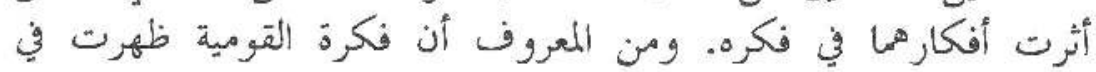

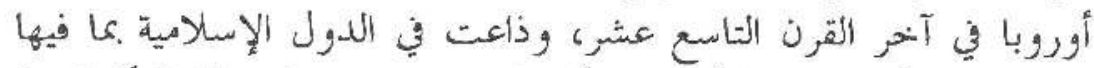

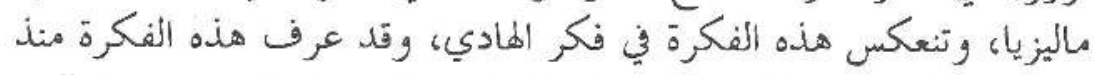

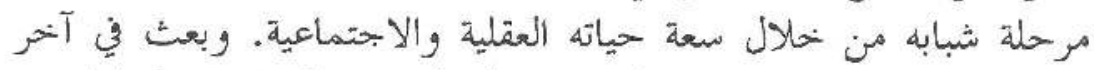

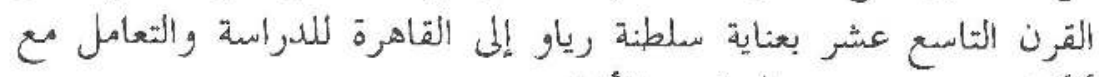
أفكار محمد عبده وجمال المثال الدين الأفغاني.

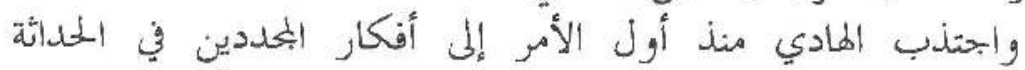

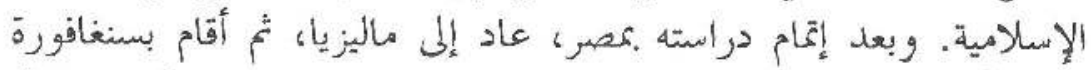

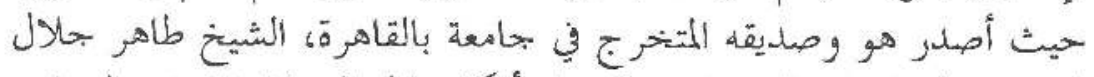

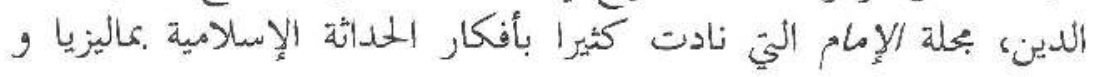


إنلونيسيا على حلى سواء؛ إلى بهانب إنشاء مؤ سمسة تربوية سميت ملرسة . إنقو

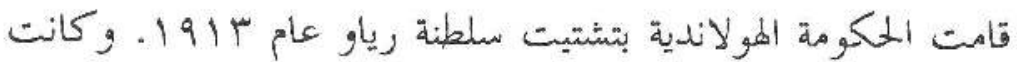

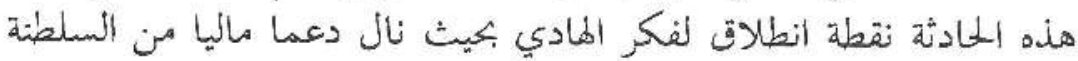

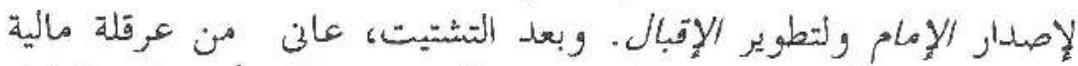

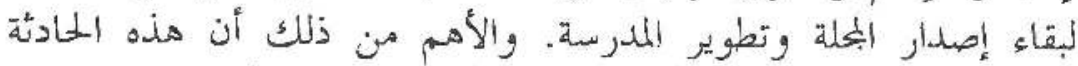

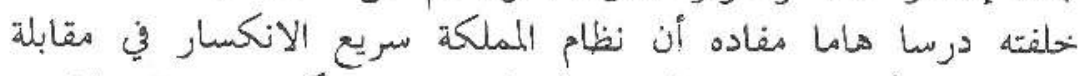

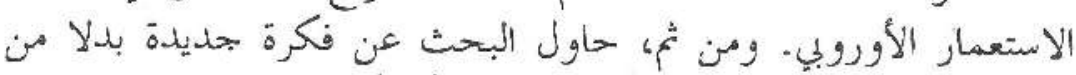

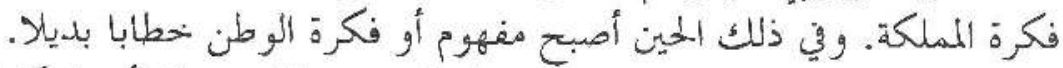

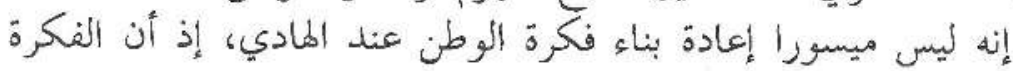

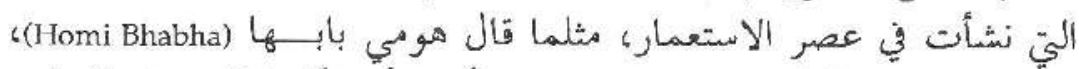

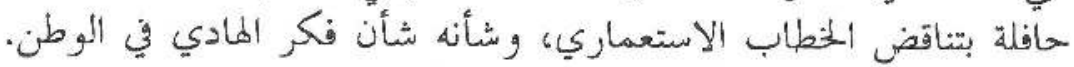

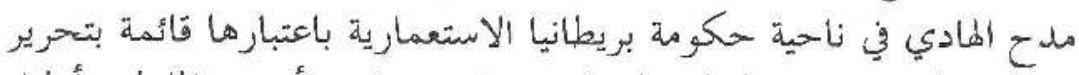

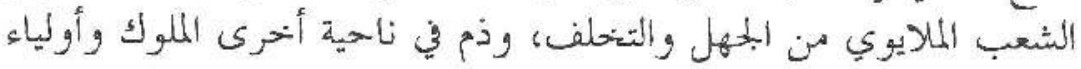

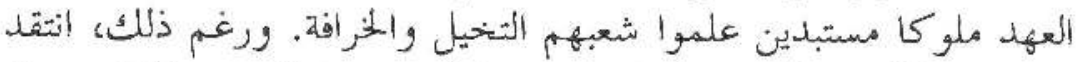

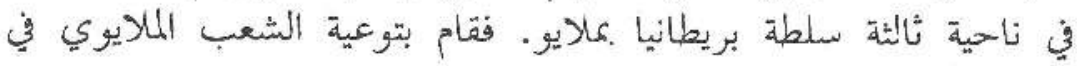
مقالاته لكيلا يخضح ويتسبلم لقوة مستعمرة.

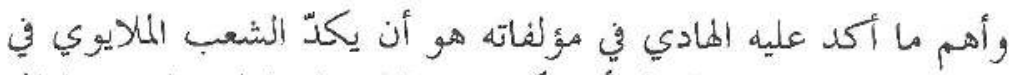

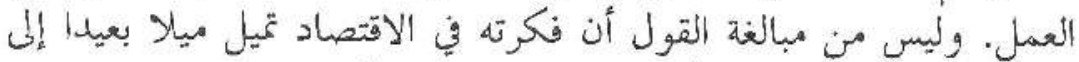

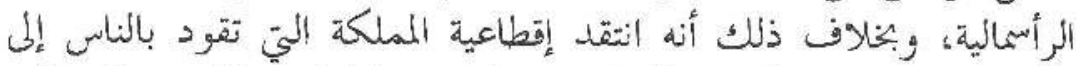

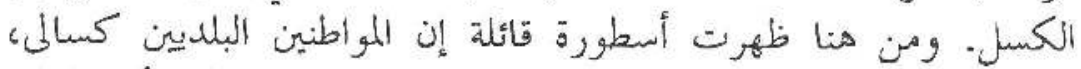

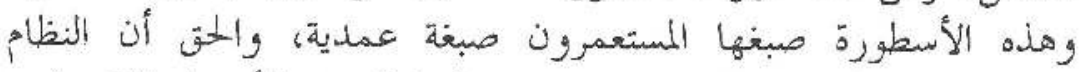

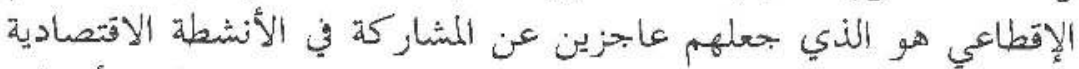

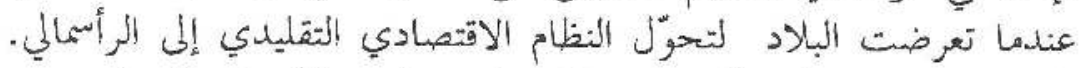

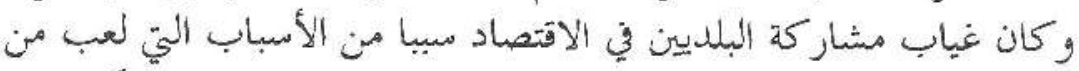

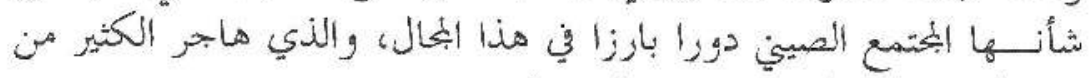

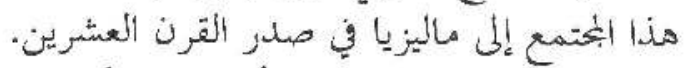

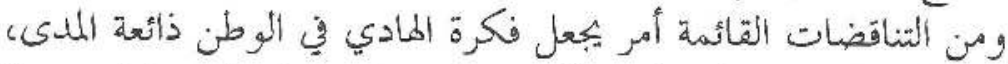

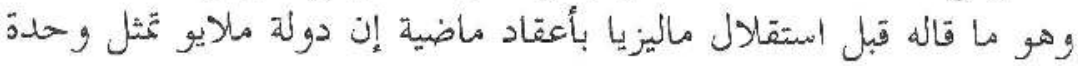

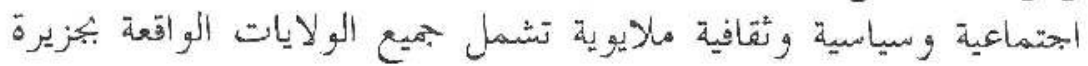
ماليزيا. 
n 31 August 1957, Malaysia gained its independence from Britain. The nation-state proclaimed by Tunku Abdul Rahman was a new invention, for even though it resembled the illustrious epoch of the pre-colonial Malay world, this was only in symbolism and imagery. The new nation-state was indelibly European in nature and secular in character. The political system, values and traditions embodied in the new polity, were acculturated from 'enlightened' Europe. The nation-state was infused with new symbols and meanings that sustained an artificial continuity with the past. Prior to the birth of nationalism, an epistemological transition had to be undertaken in order to alter the traditional worldview of the Malays.

This article seeks to examine such transition. Specifically, it focuses on the concept of watan (Ar. Watan or homeland) in the view of an early $20^{\text {th }}$ century Muslim modernist, Syed Shaikh bin Ahmad al-Hady. Watan — as proclaimed by al-Hady — had a modern and secular connotation, posing a challenge to the prevalent worldview of the Malays and kcrajaan (kingdom). The conceptualization of watan was new for most Malays. Identity was constructed predominantly in relation to the particular state in which a person resided. The significance of al-Hady's contribution was that he conceptualized watan in the sense of patrie which consequently became the pivotal basis for the construction of a modern nation-state. In this way, al-Hady played an important role in facilitating the fusing of Malay receptivity with modern European political thought, in the form of a nationalist ideology. Loyalty, in the mind of al-Hady, was no longer exclusively to the kerajaan but to a spatial homcland inhabited by the Malays. In this sense, the new concept of watan necessitates secularization of the mind.

\section{Pre-Colonial Malaya}

Prior to colonialism, all facets of Malay cultural, economic and intellectual life revolved around the concept of state in those times whereby the state was headed by the raja (king), who was not merely a political entity, but was also the central source of power moulding and dictating the lives of the members of the community. The monarch was both political ruler and vice-regent of God, a concept borrowed from the Islamic doctrine of khiläfa (caliphate). ${ }^{1}$ The basis of this polity was religion, thus endowing the secular kerajaan with spiritual significance. The role played by the raja was, as A.C. Milner noted, "as much moral and religious as political'. ${ }^{2}$ The Malay world prior to colonialism was a place where spirituality and politics developed in unison. 
Each raja ruled over a negeri, a political territory, the perimeters of which were demarcated by his spiritual influence: subject-identities were constructed in relation to a raja and not to land. ${ }^{3}$ Over time, the Malay negeri (states) came together to create a unique and united network, based on common religion, law, trade practices and literature. Of the greatest importance was that Bahasa Melayu (the Malay Language) became the lingua franca of the archipelago from the $16^{\text {th }}$ century onwards, cementing the distinctiveness of the Malay world. ${ }^{4}$ What we think of as the Malay world was therefore a network of kerajaan that stretched from Patani in Southern Thailand across to Sulu in the Southern Phillipines. Mercantile activities and the intellectual network of Muslim scholars and mystics kept this arrangement intact. ${ }^{5}$

The term 'tradition' used throughout this article refers to the 'traditional' form of Islam that for centuries has been blended with native Malay customs which 'implies both horizontal continuity with the origin and a vertical nexus which relates each movement of the life of the tradition in question to the meta-historical Transcendental Reality'. ${ }^{6}$ The extensive collective historical experience of living under the kerajaan system, together with religious and metaphysical perceptions that were critical of modern ideas, constructed the worldview of the Malays. As such, it was inconceivable to the Malays to erect a modern nation-state. Secularization, a key ingredient to making this modern nation-state, necessitated the invention of new values, politics and traditions.

\section{Syed Shaikh bin Ahmad al-Hady}

There have been numerous biographical accounts of al-Hady's life. The life story of al-Hady detailed below is derived from various sources, such as the biography of al-Hady written by his son Syed Alwi, as well as from the various available literature on al-Hady.

$\mathrm{Al}$-Hady was born in Kampung Ulu, Melaka in 1867. He was born into the illustrious Ba'alawi family, ${ }^{7}$ an Arab family who had established themselves in the Indo-Malay archipelago to carry out missionary work and trade. ${ }^{8}$ As the acknowledged direct descendants of the Prophet (known as 'sayyid'), and as a result of their rich intellectual heritage, they commanded great respect from the Malays, ${ }^{9}$ which provided al-Hady political currency among the Muslim society. During his early years, al-Hady was sent to Kuala Trengganu to receive basic religious training in a pondok (traditional educational institution).

After leaving Trengganu, he followed his father to Pulau Penyengat, the seat of the court of Riau-Lingga. In Pulau Penyengat, al-Hady was adopted by Yang Dipertuan Muda (the deputy ruler) of Riau, Raja Ali Kela- 
na. Al-Hady had the opportunity to reside in the court, which at the time was the centre of Malay literary activities. ${ }^{10}$ It was on this island that celebrated writers and poets, including Raja Ali Haji, the author of Tuhfat alNafis (The Precious Gift), composed their works. The young al-Hady was exposed to the beauty of Malay literature and he became a diligent student of the language, as evidenced by his mastery of the language in his prolific writings. While Jamilah Othman emphasizes the influence of Riau in the formation of al-Hady's ideas, ${ }^{11}$ this assertion is questionable as the royal court was in fact dominated by the teachings of the Naqsyabandi sufi-order and was the centre of traditional Islam. ${ }^{12} \mathrm{Had}$ al-Hady been influenced by Riau in the way suggested by Othman, he would have been more inclined to traditional Islam and not the modernist approach. It is more reasonable, therefore, to say that Riau inspired him linguistically but not ideologically.

At the end of the $19^{\text {th }}$ century, al-Hady was sent to Cairo in order to chaperone the first cohort of Riau princes who were continuing their studies. Mecca had long been the centre of learning for the Muslim world, yet by this time, the focus had shifted to Cairo as educational activities were more lively and modern. ${ }^{13}$ It was there that al-Hady attended the lectures of Muhammad Abduh, a proponent of modern Islamic thought. ${ }^{14}$ Abduh's lectures, together with his works and the birth of the nationalist movement in Egypt at the time, greatly influenced al-Hady's mindset. Egypt was very much the source of al-Hady's modernist ideas which he then brought to Malaya.

In 1895, al-Hady returned to Malaya and settled in Singapore, where he later coordinated the founding of the journal al-Imam (in 1906). ${ }^{15}$ Together with Cairo-educated Shaikh Tahir Jalaluddin ${ }^{16}$ and Abbas Mohd. Taha, al-Hady used the journal to promote Islamic modernism. When the Riau Sultanate was abolished by the Dutch in 1913, al-Hady lost his greatest supporters. ${ }^{17}$ Both al-Imam and al-Iqbal (the Singapore based school that al-Hady founded) were dependent on the Riau Sultanate's support. To combat resistance to the Dutch rule, whilst avoiding conflict on the scale of the Aceh War, the Dutch imposed a treaty which rendered the Sultanate powerless. ${ }^{18}$ Having refused to ratify the treaty, the Sultan was deposed and exiled to Singapore and finally in 1913 the Riau Sultanate was abolished. ${ }^{19}$ According to Linda Tan, al-Imam, as an essentially Riau-sponsored venture, was greatly affected by the abolition of the Sultanate. Lack of funds, in the end, forced al-Hady to close both the school and the journal. The abolition of the Riau Sultanate represented another critical juncture for his thought. It demonstrated the vulnerability of the kerajaan in the face of colonial aggression, underscoring al-Hady's aspiration for 
an alternative polity in Malaya. It is in this sense that direct imperialism forced al-Hady to alter his perspective on kerajaan.

After the failure in Singapore, al-Hady moved to Johor and worked as a shar' 'a lawyer but fell out with the conservative 'ulama' ${ }^{20}{ }^{20}$ In 1914, he moved to Malaka and with help from his friend, Haji Bachik, founded the al-Hadi madrasah (school), which taught reformist conceptions of Islam. ${ }^{21}$ Fervent opposition from the traditional religious elite who boycotted the school, coupled with lack of support from the Malays, forced al-Hady to close the school and move to Penang. ${ }^{22}$ Al-Hady's sojourn in Johor and Malaka attested to his inability to function in a society controlled by traditional religious establishments.

In contrast to al-Hady's other stops, Penang — al-Hady's final residence - was a liberal society. The absence of royal and religious authorities, coupled with the Chinese and non-Muslim population, provided alHady with greater freedom to promote his modern ideas than elsewhere in the Federated Malay States (FMS). The island was also equipped with infrastructure that aided in al-Hady's struggle. Printing companies, social clubs and educational institutions, for example, provided al-Hady with the necessary resources for the dissemination of his political views. ${ }^{23}$ In Penang, al-Hady founded another school, Madrasah al-Mashur. In addition, in 1926 he founded the journal al-Ikhwan and in 1928 a newspaper Saudara. $^{24}$

Journalism was the most effective means of circulating ideas in the carly twentieth century and al-Hady capitalized on this. Both al-Ikhwan and Saudara were to become key vehicles for the dissemination of alHady's reformist ideas. It was also during this period that al-Hady wrote most of his fictional ${ }^{25}$ and non-fictional works ${ }^{26}$ that not only provided him with an income but enhanced his popularity. In the Penang years, al-Hady propelled unremitting criticism at the kcrajaan, questioning the ontological foundation of the polity while proposing an alternative form of nationhood enshrined within his concept of watan. He continued to write prolifically until his health began to decline and he died aged sixty-seven of a neurological condition on 20 February 1934.

Al-Hady's ideas, unsurprisingly, reflect his life experiences. Specifically, the life story of al-Hady illuminates three important points. First, alHady functioned within the colonial structure and relied on it. His work was severely curtailed when operating within the traditional Malay structures such as those in Johor and Malaka. ${ }^{27}$ Penang and Singapore, directly under British protection and ethnically diverse, allowed him more freedom to teach and publish his ideas. ${ }^{28}$ Secondly, al-Hady's major source of inspiration was Islamic modernism and the nationalist movement in Egypt. 
This in turn positioned al-Hady as a modernist who, like Abduh, ${ }^{29}$ advocated Islamic modernism to solve religious tensions within Islamic thought as well as existing socio-economic and political problems. Thirdly, direct imperialism, as experienced in Riau, led him to reject traditionalism.

\section{Circumlocutory Imperialism}

The general theory used in this article I have called circumlocutory imperialism. Following Syed Hussein Alatas, I define imperialism as 'the subjugation of one people by another for the advantage of the dominating one' $\cdot{ }^{30}$ Specifically, the term 'imperialism' is strictly used in the context of the growth of capitalism and the emerging world system. There were two fronts of imperialism: direct and indirect. The direct imperialism came straight from Europe to Malaya in the form of military and bureaucratic control, establishing direct rule in the Strait Settlements and indirect rule in the Federated Malay States. The second front of imperialism was indirect and intellectual in nature. It was in the form of epistemological domination of the subjugated. Direct European imperialism brought the political and economic failure of the traditional polity, which challenged the spiritual and mystical power associated with the raja and his polity. Those who witnessed foreign control on their polity were consequently inclined to rethink the ontological foundation of the polity. The subjugated not only questioned their traditional epistemological framework, but also sought alternatives, including European thought. For al-Hady, this was the case as he witnessed the abolition of the Riau-Lingga Sultanate. Changes conditions in this regards cannot be separated from the colonial encounter. To return to Alatas, 'the political and economic structure of imperialism generated a parallel structure in the way of thinking of the subjugated people' ${ }^{31}$

The central component in the alteration of traditional Malay worldview was secularization. The definition of secularization employed in this article is the deliverance "first from religious and then from metaphysical control over his [her] reason and his [her] language'. ${ }^{32}$ For S. M. N. al-Attas, the integral components of secularization are "the disenchantment of nature, the desacralization of politics, and the deconsecration of values'. ${ }^{33}$ Challenges to the traditional Malay polity can only come after the secularization of Malay worldview, for the ontological foundation of the kerajaan was both spiritual and metaphysical in nature. In order to form a liberal and modern polity to substitute the kerajaan, a different epistemological ground had to be constructed.

The adoption of Western epistemology in the case of the Malays did not come directly from Europe but through a third agent, Egypt. It was in 
Cairo that the alien values were veiled with an Islamic mantle. The development of what Michael Laffan called 'Cairene discourse' induced a fundamental shift in the Islamic worldview. ${ }^{34}$ Western-influenced Muslim modernists such as 'Abduh ${ }^{35}$ tried to reconcile modern Western values with Islam. This urge was brought about by the perceived political, economic and technological superiority of Western European power, first witnessed during the Napoleonic conquest of Egypt. Dissatisfaction with traditional Islamic thoughts and values was further solidified by the collapse of the Mameluk dynasty in Egypt at the hands of the French armies. The construction of this synthesis represented an effort to impede secularization. ${ }^{36}$ The Islam of 'Abduh, as well as another famous Muslim modernist of the time Jamal al-Dīn al-Afghānī, was the product of colonial encounters.

In attempting to reconcile Western and Islamic thoughts, both 'Abduh and Afghāni pushed Islam into the colonial discourse. That is, Islam entered the colonial sphere and religion was remoulded in the image of the progressive and enlightened Europe. Aspects of Islam that did not fit this model were discarded while those which were suitable were accepted. What followed was essentially a secularization of Islamic thought, in spite of persistent Islamic overtones. These overtones, such as the sustained usage of Islamic key-terminologies, possessed very different connotations after its semantic transformation to a more secular denotation. In this way, the modification of religious doctrines was the direct result of the political and economic hegemony of Western European states. These doctrinal adjustments were significantly palpable in changing the nature of fundamental concepts.

The influence of the Cairene discourse did not limit itself to Egypt and the Arab world. Journalism and the international network of intellectuals centred on 'Abduh and his disciples guaranteed the spread of the Cairene discourse throughout the wider Muslim world. ${ }^{37}$ Many students from Malaya studied in Egypt. Moreover, the reformist Egyptian journal, alManar was in circulation in 'the Malayo-Indonesian archipelago' as early as $1898 .{ }^{38}$ Intellectuals such as al-Hady played a strong role in promoting the Cairene discourse in Malaya.

The Cairo-educated Muslim reformists introduced the ideology from the West via Cairo to the peninsula. Introducing an alien worldview with its accompanying concepts to the conservative Malay population, however, was a demanding task which required a restructuring of the traditional epistemological framework. In addition, the language, saturated as it was with the traditional worldview, had to be reformed and was undertaken in a subtle and delicate way to guarantee its positive reception. The intellectuals had to speak in the same language as the people, which caused them 
to give the ideology an Islamic 'face' and to 'sugarcoat' Qur'anic verses to win acceptance..$^{39}$ Fazlur Rahman referred this approach as the 'janusfaced attitude', in which intellectuals presented their modern views in a traditional manner. ${ }^{40}$ This is a fitting description of the Cairo-educated Muslim modernists.

Constructing a public sphere in which to socially anchor reform was also necessary. ${ }^{41}$ Moreover, they also had to eliminate resistance to their agenda. In the case of Malaya, the most fervent opposition was from the traditional 'ulamā' (scholars) who were also connected with the sufi (mystical) brotherhoods. The sufi-'ulamā' have long been the vanguard of the orthodox tradition of Islam, especially Islamic epistemology. ${ }^{42}$ They also preserved the eschatological leaning of Islam. The modernists saw the sžfș-'ulamā' as obstacles to the realization of their agenda. In this way, they became the natural enemy of the modernists who were trying to impose an alien and secular ideology, which explains the antagonism of the modernists towards the traditional Islamic establishment.

The epistemological foundation of the new polity was very much derived from the West. In this regard, Partha Chaterjee's description of nationalism, which 'simultaneously rejects and accepts the dominance, both epistemic and moral, of an alien culture ${ }^{93}$ is also applicable to our discussion of new polity. Seen in this way, the modernists subversively conditioned the Malay mind into accepting an alien epistemology, contrary to the pre-existent worldview. In this respect the second front of imperialism occurred from within.

Circumlocutory imperialism projected a power relationship between Europe and Malaya, facilitated by Egypt. The influence of colonial capitalism in this regards cannot be ignored. That is, modernists like al-Hady were working within the structure of colonial capitalism, while simultaneously promoting it. In this sense, their ideas should be viewed in the light of contemporaneous economic conditions in Malaya. One cannot separate the power relations encapsulated in circumlocutory imperialism from the economic conditions related to colonial capitalism because both were intricately intertwined. The history of power and domination, albeit at the intellectual and epistemological levels, cannot be separated from the history of capitalism. Ultimately, it was political and economic imperialism that resulted in intellectual and epistemological imperialism.

The theory of circumlocutory imperialism will serve as a template for understanding the thoughts of al-Hady, in particular his conceptualization of watan. This article will now trace the origin of watan, its politicization in the light of colonial encounters in the Middle East. Before considering Malaya at the turn of the century the importance of the Middle East must 
be highlighted. It was here that the concept of watan underwent semantic transformation in the late $19^{\text {th }}$ century.

\section{The Semantic Transformation of Watan}

The semantic transformation and the politicization of watan were the direct result of modernization and the diffusion of European thought into the Muslim world, which resulted from the colonial encounter towards the end of the $19^{\text {th }}$ century. Traditionally, watan was a term used to denote one's birthplace or place of residence birth without any formal political connotation. ${ }^{44}$ The watan that was proposed by al-Hady, in contrast, was politicized to the extent that it focused on loyalty and identity.

In classical Arabic usage, the definition of watan was narrow and personal. Ibn Mandzür defined it as 'the place where one resides' ${ }^{45}$ E.W. Lane defined watan as 'a man's settled place of abode or his place of constant residence'. ${ }^{46}$ Another leading Arab lexicographer, al-Jurjānī, divided watan into two, with al-watan al-ashi as the birthplace of an individual and his place of residence, while al-watan al-iqämah denoted a place in which an individual stayed but was not a permanent residence. ${ }^{47}$ What these definitions indicate is that watan had a personal nuance rather than a political nuance. As Bernard Lewis asserted, watan was not a focus of loyalty, and only to a limited extent a focus of identity. ${ }^{48}$

For Muslims, identity was largely based on being part of the transnational Islamic community, the umma. According to Muhammad Asad, the linguistic meaning of umma is 'a group of living beings having certain characteristics of circumstances in common' ${ }^{49}$ In Islamic belief, the whole of humanity was created as a single umma as stated explicitly in the Qur'an, 'And (know that) all mankind were once but one single community, and later did they begin to hold divergent views..$^{50}$ Islamically, identity was constructed in terms of a belief-system not of one's place of origin or one's race. During the formative era of Islam, tribal affiliation was the focus of identity among Arabs. Once an individual embraced Islam, he or she altered their loyalty to that of a new Islamic identity. ${ }^{51}$ Faith itself became an important element in loyalty and identity. Although one's place of origin was still relevant to identity, it lacked formal political significance.

The establishment of an imperial Islamic power, first by the Umayyads and then by the Abbasids, did not disturb the political unity of the umma. Faith alone became the unifying force behind the polity of both empires. ${ }^{52}$ With the demise of the Abbasid Empire and the proliferation of power into a number of independent states in the $8^{\text {tb }}$ century, the political unity of the 
umma was shattered. ${ }^{53}$ What remained was the conception of umma as a law-based community. Even when the Islamic world was divided into a number of polities, the people remained as adherents to the Islamic law, the $\operatorname{shari}^{c}$ a. The notion of umma as a law-based community became an adhesive force that solidificd the remaining umma. ${ }^{54}$ The characteristic of this unity, however, was a cultural and religious community, which was still seen as the focus of identity but not of political loyalty.

The disintegration of the Islamic empire into a number of autonomous nations altered the focus of political loyalty. The ideology of power was transformed into the idea of dawla (dynasty) 'applied to a particular clan'.55 A person, therefore, developed two levels of identity; religious and political, which gave rise to 'an embryonic distinction between government (dawla) and religion (din). ${ }^{56}$ Identity was formed in relation to the religion and the notion of umma, while political loyalty was confined to the dawla. As for the term watan, it remained in the vocabulary of the Islamic world with personal connotations until the mid- $19^{\text {th }}$ century.

The military campaign of Napoleon, which brought down the Mameluk dynasty in Egypt in 1798, provided the impetus for an intellectual revolution in the Middle East. ${ }^{57}$ Napoleon arrived not only with his army but with scholars. The conqueror did not only establish a colony, but also the Institut d'Egypte with the aim of le progress ct a propagation des lumieres (progress and the propagation of knowledge). ${ }^{58}$ The arrival of Napoleon marked the introduction of new power and knowledge into the Muslim world. The ambiguous relationship between colonial power and progressive knowledge became the pattern that characterized the relationship between the Europe and the Muslim world throughout the years that followed. The abhorrence of foreign intrusion was balanced by the admiration for modern European ideas.

The failure of the Napolconic military campaign in Egypt left the country with a power vacuum which was filled in 1805 by an Albanian military commander, Muhammad Ali. ${ }^{59}$ Ali, who has witnessed the modern military might of the French army and was as well deeply influenced by their push for 'enlightenment', was convinced that the only way forward for Egypt was to undertake modernization. ${ }^{60} \mathrm{He}$ therefore established military training colleges, modern presses and a school of languages, to modernize Egypt both militarily and intellectually along European lines. In addition, Ali sent a group of Egyptians to study in France, which became the pivotal point in the introduction of the concept of nationalism to the Arab world. Ali himself was a product of the colonial encounter, in which his disdain for the Western power was ambiguously matched by his appreciation for Western thought and values. 
One of the students sent to Paris by Ali was Rifā'a Răfị al-Tahțāwī. He arrived in 1826 and became acquainted with the works of the major French thinkers, notably Montesquieu, Rousseau, Voltaire and Racine. ${ }^{61}$ He learnt European political ideas including the concept of patrie (fatherland). Upon returning to Egypt in 1831, Tahțāwĩ worked in the language school and translated a number of influential French works including Montesquieu's Marseillaise. ${ }^{62}$ It was in this particular work that Tahtawi used the word watan for the French patrie, thereby, 'I'amour de la patrie' became 'hubb al-watan' ${ }^{63}$ Moreover, he stressed that without love for one's country, civilization must be condemned to perish. ${ }^{64}$ Critically, Tahțāwī, whose home-village was Tahțā, used watan to describe Egypt. That is, watan ceased to be a term denoting one's place of origin; rather it denoted something much greater, such as one's country.

Influenced by French ideologies, Tahțāwi had transformed the narrow and personal concept of watan into a concept of fatherland imbued with patriotism. Mutual rights and obligation, which had previously solely existed in the preserve of religion, became the characteristic of both religion and patriotism. ${ }^{65}$ Egypt was also beginning to be conceptualized as a patrie separate from the rest of the Ottoman Empire, echoing Muhammad Ali's separatist tendencies. Starting with Tahțāwi, the concept of watan was infused with intense loyalty, which formerly was reserved for dawla, marking the commencement of the politicization of watan.

The paradoxical relationship between Europe and the Middle East was also highlighted by the Ottoman Sultan, Selim II. In 1827, the Sultan ordered the rebuilding of his army following modern European fashion. Similar to Ali, Selim also sent students to study in Europe in an effort to force Europeanization on the empire. ${ }^{66} \mathrm{As}$ the Sultan became committed to European reforms and as economic and military pressure on the empire increased, these students were appointed to the highest posts both in military and civilian bureaucracy. ${ }^{67}$ The new elites forced the Sultan to embark on a reform policy that sought to abolish taxation of farming, standardize military conscription and eliminate corruption. What followed was two royal decrees that explicitly stated the new direction of the empire, which was popularly known as the tanzimat (reorganization) ${ }^{68}$ For many, however, the tanzimat appeared as a triumph of the West over Islam. As Lewis noted in his history of Turkey, the reforms were seen as "the forcible imposition' on a Muslim country, with the encouragement, if not the insistence, of European powers, and with the help of European experts and advisers'. ${ }^{69}$ The result was the emergence of a group of intellectuals (also educated in Europe), known as the Young Ottomans, who sought to 
reconcile the new institutions of the tanzimat with the Islamic political tradition.

The most prominent Young Ottoman was an intellectual and poet, Namik Kemal, who popularized the Turkish term for watan, vatan, in the Ottoman domain. For Kemal, who was also influenced by Montesquieu and Rousseau, vatan was 'a sacred idea resulting from the conglomeration of various noble feelings such as the people, liberty, brotherhood, interest, sovereignty, respect for one's ancestors, love of the family and childhood memories' ${ }^{70}$ The vatan, in his view, was the territory of the Ottoman Empire, yet like Ernest Renan, ${ }^{71} \mathrm{Kemal}$ defined vatan as 'an emotional bond in which the memories of ancestors, the recollections of one's own youth and earliest experiences all had a place'.$^{72} \mathrm{He}$ also had a clear concept of citizenship and rights and responsibilities associated with it. ${ }^{73} \mathrm{Ke}-$ mal, influenced by European concept of patriotism, introduced a new and political meaning of vatan to the Turkish vocabulary, which was antiEurope but also relied on European ideas.

The historian Abdullah al-Ahsan erroneously asserted that Islam was the sole basis of Kemal's vatan. ${ }^{74}$ While it is true that Kemal was a devoted Muslim who upheld the shar ${ }^{\prime} a$ as fundamental to good governance, there are two points that illustrate the degree of secularism in Kemal's thought. First is the intense loyalty to the fatherland. His identity and loyalty was not constructed in respect to the umma but to the Ottoman territory. In his famous play Vatan, Kemal affirmed the importance of love and loyalty an individual owed to his or her country. ${ }^{75}$ The play was full of rousing appeals to the Ottomans, not the Muslims, to defend their country against its enemies. Secondly, Kemal's idea of unity replaced the previous conception of people living together but separated by religious barriers. ${ }^{76} \mathrm{Kemal}$ 's understanding of watan was directly opposed to the concept of umma and hence it was to a large extent infused by secular conceptions derived from Europe.

One of the most celebrated Islamic thinkers and activists of the period, Jamaluddin al-Afghani, travelled around the Muslim world preaching the idea of Pan-Islamism. ${ }^{77}$ Afghani saw Pan-Islamism as the way to galvanize Muslims and to rouse them to challenge Western encroachment on the Islamic world. By inviting people to political activism, Afghani transformed Islam as a religion into a political ideology. ${ }^{78}$ Although it seemed that Pan-Islamism was opposed to watan consciousness, in a way it served as a critical transition from Islamic to national loyalties by giving a new nationalist emphasis to Muslims that later evolved into local nationalism. Issues such as hostility to the West, identification with a glorious age in 
the past, sentiments of the superiority of the indigenous culture and appeal for the common goal of unity, were the teachings of Pan-Islamism that immediately contributed to the formation of watan consciousness. ${ }^{79}$ The principal result of Pan-Islamism was its contribution to the formation of national consciousness.

In the case of Egypt, Afghāni's thoughts contributed greatly to politics as emphasized that leadership was not the privilege of a particular race or family and that a ruler's retention of power was contingent on performance.$^{80}$ Afghānī's leading pupil, the Egyptian Muhammad 'Abduh continued his teacher's activism but developed it into a more nationalistic framework. In his political writings, Abduh explicitly stated that 'the finest of the faces of unity is that of the homeland, because on this disagreement and contention are impossible'. ${ }^{81}$ In addition, he defined watan as the 'place to which you belong and in which you have rights and towards which your duties are known'. ${ }^{82}$ This indicates that 'Abduh's watan was borrowed from the French patrie and that earlier thinkers such as Tahțāwi and Kemal had influenced him. 'Abduh, therefore, spoke as a nationalist who regarded the authority of the state to be underscored by political and geographical boundaries rather than religious allegiance. By doing so, he drove Islam back into the private sphere.

'Abduh's conception of watan dismissed the dichotomy between Muslim and non-Muslims. In classical Islamic political thought, the people of the book, which consisted of Christians and Jews, ought to be dealt with as dhimmis (protected people). ${ }^{83}$ Their religious freedom was protected by the state but they were differentiated on the basis of their conviction. Abduh challenged this dichotomy by arguing the equal status of Muslims and non-Muslims, bound by the concept of citizenship tied to the land. The most important contribution of 'Abduh, which al-Hady followed, was his notion of the compatibility of Islam and modernism, which in 'Abduh's view was the precursor to the development of nationalism.

Nadav Saffran noted inconsistencies within Abduh's thought. That is, he asserted the love of the fatherland as a religious duty, which accorded very well with the aims of the nationalists, but he still maintained that the community of the believers (the umma) as the basic political unit. ${ }^{84}$ In Saffran's view, the inconsistencies were due to 'Abduh's superficial understanding of modern European thought. This, however, is not the case. Abduh discussed the works of Auguste Comte, delivered a series of lectures based on the history of Francois Guizot and even travelled to England to meet Herbert Spencer. ${ }^{85}$ In addition, 'Abduh's thought developed over a period of time when the social context constantly changed, which explains their fluidity. Some inconsistencies were also the result of his 
ambiguous relationship with the colonial powers. He cooperated with the colonial structure to purify Islam from superstitions, indicating the notion that Islam and progress was formed in the image of Western positivism. It is no surprise that Lord Cromer, the ruler of Egypt, saw 'Abduh as the natural ally of the European reformer. ${ }^{86}$ Islam, progress and watan, in Abduh's view, had created an incoherent discourse with no clear-cut boundary, full of paradoxes which were the natural product of the ambiguous nature of the colonial encounter.

The last intellectual examined is the more secular Mustafa Kamil. Kamil believed that there was nationhood for Egyptians, yet that nationhood was part of larger units such as the Ottoman, Islamic or Eastern world. ${ }^{87} \mathrm{He}$ also emphasized the need to adopt the positive aspects of Western civilization. ${ }^{88}$ Educated in France, Kamil valued unity based on shared sentiment and responsibility, that is, patriotism. ${ }^{89}$ For Kamil, patriotism was the key to the success of the Europeans and that loyalty should be based on the land of Egypt, not on religion or language. He also claimed that there was no conflict between religion and nationhood as true religion should teach patriotism. The significance of Kamil's ideas, however, does not lie in the discursive realm, but in his political activism: his success in mobilizing large sections of the educated population behind slogans of patriotism. Kamil can be seen as the first Muslim personality who brought the concept of patriotism from its intellectual realm to the populous sphere of political activism.

Having surveyed a number of influential proponents of patriotism and nationalism, there are a number of issues that should be highlighted. First is the issue of the role of the intellectuals. Edward Shils noted that the role of the intellectual was to introduce and present ideas and form expressive disposition within a society. ${ }^{90}$ Intellectuals do not only create and form ideas; they communicate them to the rest of society. These intellectuals, who derived their thought from Europe modified them to fit their societies. This was done by appropriating ideas into popular media as well as infusing them with religious language to produce a mobilizing effect. A concept like watan was therefore a product of the colonial encounter, in which religion interacted with colonial discourse to produce a site of paradox and ambivalence. The relationship between colonial structure and religion in the form of Islamic modernism, therefore, served as an example of how the 'sacred" may be employed 'to develop a system of political legitimacy and to aid in mobilizing the community for secular ends'. ${ }^{11}$

The second issue is that the ideology of such personalities as those mentioned above were partially based on a defeatist mentality. They formed their ideas in the time when the Muslim world was frail and fragile in 
comparison to the mighty Europe. This in turn produced the logic of adopting modern Western systems in order to be successful. The basic assumption was that science and knowledge were value-free and that civilization and religion were two separate entities. ${ }^{92}$ Once this reasoning was accepted, the result was inevitable: separation of state and religion. A Muslim reformist like Abduh did not want this to happen, yet by striving for the compatibility of Islam and modern Western thought, he had opened the door to secularism.

The last issue is the absence of traditional Islamic voices in the debate on modernity. Talal Asad argued that the modern public sphere in the West, contrary to the idealization of Habermas, has always been a space of social exclusions. ${ }^{93}$ That is, those who were invited to participate in the public sphere were those who were familiar with Western ideas and practices. While the intellectuals participated in the public sphere because they were accustomed to European ideas and practices, the traditional scholars, mystics and savants, remained absent from the debate as they lacked the prerequisites that could enable them to enter. The expansion of public sphere, therefore, weakened the authority of traditional voices.

While in Egypt, al-Hady was exposed to the formation of nationalist consciousness. He was reported to have attended the lectures of Abduh and translated a number of his works into Malay. ${ }^{94} \mathrm{He}$ was also familiar with the other intellectuals as their ideas were discussed in al-Hady's periodicals. The Middle East's experiment with modernity, therefore, was the first stage of 'circumlocutory imperialism', where Western enlightenment ideas were transmitted to the Muslim world. The next section focuses on the concept of watan in the ideas of al-Hady and looks at how he appropriated ideas that were discussed in the Middle East with Malaya.

\section{Syed Shaikh al-Hady \& Watan}

The first people to utilize and popularize the concept of watan in Malaya was the Cairo-influenced al-Imam group who were responsible for the publication of the reformist journal of the same name. Syed Shaikh alHady was a prominent member of the group. Although he frequently used the term, he never systematically defined what he meant by watan. It is therefore the aim of this section to reconstruct al-Hady's understanding of watan. The assumption of this article is that the meaning of watan, as understood by al-Hady, is implied in other things he said. For that reason, this section examines al-Hady's responses to the presence of the British, Malay Royalties and foreign immigrants from China and India, while extrapolating the meaning of watan as implied in these responses. By doing so, reconstructing al-Hady's conception of watan is possible. 
The influence of the Cairene discourse as examined above, which is overlooked by many writers, ${ }^{95}$ must be kept in mind as it served as the background of al-Hady's ideas. Also paramount to the Cairene Discourse as the milieu of al-Hady's thoughts is the expansion of colonial capitalism in Malaya brought about by increased profits derived from the tin and later on the rubber boom in the beginning of the $20^{\text {th }}$ century.

The reconstruction of al-Hady's thought is an intricate and complicated exercise as they consist of paradoxes, which often contradict each other. One can understand this phenomenon through what Homi Bhabha termed as 'the ambivalence of the colonial discourse', which produced ambivalent reactions on the part of the colonized. ${ }^{96}$ For instance, on the one hand, the British promoted the expansion of colonial capitalism but on the other hand it protected the feudal system of the Malay Kingdoms. ${ }^{97}$ This resulted in a multitude of responses from the colonized.

The first response to be examined is in relation to the presence of the British. The 'ambivalent' nature of al-Hady's thoughts can be clearly seen in his treatment of the British. In a number of his writings, al-Hady praised the British as the protector of the Malays from the despotic reigns of the Malay Kings. At his most extreme, he described the British as 'the army of Rabb al'alamin (God of the universe) sent here to free us from the prison of stupidity, cruelty and fierceness of our own rulers, because the English are smart, respect the rules of government, world peace and prosperity ${ }^{9}{ }^{98}$ In a radical departure, al-Hady utilized a Qur' anic verse, 'my servants, the righteous, shall inherit the earth" ${ }^{* 99}$ to justify the presence of the British in Malaya. We can pinpoint this as the moment when Islam as a religion entered the colonial discourse.

Colonization was justified by the Darwinian view that superior people rule over inferior people. As the military might of the British underscored their superiority over the Malays, colonization was normalized by this theory. Furthermore, in using the Qur'an to justify colonialism, European Enlightenment ceased to be the only justification for the colonial project. On replying to a move by the Kelantan 'ulamā' to ban al-Hady's newspapers al-Ikhwan and Saudara, he wrote that Kelantan is a state:

... which through the implementation of British justice, has just emerged from barbarism into the modern world and in which it seems there are still people who believe in the words of the religious authorities who have never opened their cyes to the dawn of modernity and freedom of thoughts such as we have under the protection of the three-coloured flag. 16

In another article written as a response to the question of whether the Malay could cscape annihilation and extinction, al-l lady affirmed that there 
was nothing wrong with the actions of the European nation entering a foreign land and exploitating its resources. In his view, they were just 'pursuing the demands of a God-given human nature, common to all human being, which is to demand superiority' ${ }^{101}$ He continued that this human nature was what Darwin called 'the law of competitiveness' and therefore, whoever was weak would surely be destroyed and annihilated. ${ }^{102}$ Within the colonial discourse, al-Hady reconciled Darwin and Islam by supporting Darwinian theories with Islamic groundings.

Al-Hady's sympathy towards the British is multi-factorial, ${ }^{103}$ but in particular it relates to the more subtle nature of imperialism, enshrined in the founding of 'power'. That is, a process of 'othering', whereby the colonial power constructs itself as 'the self'. This othering, became a process, according to Gayatri Spivak, when colonists constructed its others as subjects. Othering, therefore, is a dialectic by which the big 'other' who colonized created small others, who were constructed as obedient and thankful subjects. ${ }^{104}$ Seen in this way, al-Hady became a small other, who remained loyal and subservient to his colonial masters. In this light, Mat Ton's statement that the people behind al-Imam developed an anti-imperalist attitude ${ }^{105}$ must be rethought. Therefore Laffan rightly noted that Mat Ton overemphasized the anti-colonial aspect of the journal. ${ }^{106}$

While al-Hady was familiar with the thoughts of Charles Darwin, he only spoke Malay and Arabic. Al-Hady's library consisted of many European books that were translated into Arabic in the Arab metropolises like Beirut and Cairo. ${ }^{107}$ At this time, Darwinian theories were already spreading through the Middle East, popularized by a controversial doctor named Syibli Syumayyil. ${ }^{108}$ The genealogy of al-Hady's thoughts did not emanate directly from Europe but came through the Arab world, thereby establishing the circumlocutory route from Europe.

Simultaneously, al-Hady was also a fervent critique of the British encroachment in Malaya. In an article published in al-1khwan, al-Hady wrote, "for if we are conscious and still possess the faculty of thought, then how can we allow another people to rule over us, to be our guardian in our beloved watan?'109 In the same article he also warned the Malays not to be deceived by the wealth and prosperity in Malaya as they were reserved for the British and European capitalist establishments. ${ }^{110}$ In his detective novel, Cetera Rokambul, al-Hady indirectly attacked the British. In this novel, set in India, the British defeated and controlled the Muslims not by guns but by distributing opium. Another strategy adopted by the British, in al-Hady's fiction, was signing treaties with local rulers. " 1 By shrouding his criticism of the British in stories and indirect 
critique, al-Hady saved his newspapers and publishing house from prosecution by the colonial power.

Al-Hady found from past experiences that participation in the politics of government and criticism was ineffective against the British. ${ }^{12}$ Perhaps he was alluding to his involvement in the anti-colonial Rushdiyyah club in Riau, which developed into an anti-Dutch movement and led to the abolition of the Riau sultanate. ${ }^{113}$ Another failed anti-imperialist movement that he witnessed was the mutiny of the $5^{\text {th }}$ Light Infantry in Singapore on 15 February 1915. ${ }^{114}$ There were many other minor rebellions, which seems to have persuaded al-Hady to avoid direct political activism. ${ }^{115} \mathrm{Al}-\mathrm{Hady}$ was opposed to British exploitation of Malay land for Europe and ruling over the watan. It is apparent, therefore, that in his view, the British were useful in limited ways, but once that limit has been transgressed, then the British should be subjected to indirect hostility. The British were seen to usurp of the guardianship of the watan. The watan, in the mind of al-Hady, was exclusive to the Malays alone.

The second response is in relation to the Malay royalties. Within alHady's responses to the existence of traditional Malay royalties lies some hints that can shed some light on the concept of watan. The kerajaan was diffused with spiritual and religious significances that created a mystical aura. The sacred force, surrounding a king was daulat, a word that came from the Arabic dawla, meaning the mystical power of the king which gave him full power over his subjects. This included presenting a subject with a nama (good reputation, which was the aim of every subject) and condemning ungrateful subjects with the charge of derhaka (disloyalty). ${ }^{116}$ The presentation of good nama to a subject did not necessarily indicate the positive quality of the subject. R.J. Wilkinson noted that there were many less important people who possessed the most reputable nama. ${ }^{117}$

In the view of al-Hady, the system of nama was nothing but nonsense. He believed that real praise should be reserved for those who strove for the betterment of their community, nation and watan. ${ }^{118}$ Sultan Abubakar of Johor, for instance, was remembered not because of his title and medals but because of his work in rescuing his state from the British control. ${ }^{119}$ In al-Hady's opinion, the traditional system of nama, given to those most loyal to the raja was merely based on imagination, dreams and false honour. ${ }^{120}$ From this attitude we can infer that al-Hady, had been exposed to the idea of rationalism from Europe through Egypt. He began to measure the traditional system against the standard of European rationalism, and hence this system became devoid of meaning.

In his book Kitab Ugama Islam dan Akal, al-Hady further challenged the feudal system by affirming the equality of all, whether they were kings 
or beggars. ${ }^{121} \mathrm{Al}$-Hady saw Malay traditionalism as an obstacle to progress. In addition, he criticized the Malays for being lazy and irrational, which resulted in their failure to partake in the expanding capitalism. The representation of the Malays as lazy was a colonial construct as a result of the resistance of Malays to work in the capitalist sector of the economy. ${ }^{122} \mathrm{By}$ the end of the $19^{\text {th }}$ century, however, the Malays themselves had begun to identify with the constructed image of lazy Malays. The result of this was the rise of an inferiority complex among the Malays that led them to condemn traditional values, which were seen as 'an obstacle to their adaptation to capitalism'. ${ }^{123}$

In contrast, values which are compatible with progress such as prudence, frugality and toil were stressed by al-Hady. ${ }^{124}$ Shaharudin Maaruf claimed that we have to read al-Hady's book in the light of the expanding colonial capitalism that excluded Malays. ${ }^{125}$ The book itself was the direct product of expanding colonial capitalism while at the same time seeking to justify it. The Malays, however, were not excluded from the expanding colonial capitalism. Rather, the traditional and non-capitalistic economic ethos of the Malays discouraged them from partaking in colonial capitalism. ${ }^{126}$ Alatas accurately asserted that it was rational for the Malays to remain in their rice field rather than to work in the tin mines or the rubber plantation to enrich the colonial masters:

It was only when they were judged by the criteria of colonial capitalism that they were found wanting. The ideology of colonial capitalism evaluated people according to their utility in their production system and the profit level. ${ }^{12}$

From this point of view, al-Hady's description of the Malays can be seen as the direct product of their colonial representation. In addition, alHady's standard of rationality was also the product of the ideology of colonial capitalism. Failure to read the book in the light of the expanding colonial capitalism will result in the inability, such as in Milner's work, to address the question of why al-Hady entered 'the new discourse of politics', that is, the discourse of progress and rationalism. ${ }^{128}$ For al-Hady, the rational path for the Malays was to actively partake in colonial capitalism. The direct result of this paradigm is the dismissal of the spiritual and mystical values of raja and the traditional feudal system. Kitab Ugama Islam dan Akal, therefore, sought to reconstruct Islam in a manner that could be reconciled with capitalism.

The loyalty that was formerly due to the raja was now directed to the watan. The land was conceptualized as the locus of loyalty and love. In his novel, Hikayat Faridah Hanum set in Egypt, both the male and female protagonists were described as intelligent, noble and educated youth of Egypt 
who loved and remained loyal to their watan. ${ }^{129}$ There was even a scene when Shafiq Effendi, the male hero, swore by the most beloved watan. ${ }^{130}$ This incident is un-Islamic as Muslims are prohibited from swearing except by the name of God. For the Malays, the scene was radical and problematic, and yet for the Egyptians it was normal. The contrast between the Malays and the Egyptians became the successful motif for alHady, in which Egyptians were portrayed as nationalistic and modern, thereby constructing a new exemplar for the Malays. In another case, Faridah, the heroine was sad to sec her homeland being subjected to British control. Rather than blaming the British, she blamed the political and religious authorities. ${ }^{131}$ Loyalty to watan was thus the highest form of loyalty as kings and ministers could be blamed for the weakness of the watan. In other words, kings did not have the hereditary and spiritual right to rule, what they had was merely duty to the collective watan, in which their success of failure depended on their services to the watan. Within this logic, Malays moved from being subjects to citizens.

The last issue to be examined in extrapolating al-Hady's conception of watan is his repose to the arrival of foreign migrants in Malaya. In the middle of the $19^{\text {th }}$ century, the demand for tin increased rapidly. ${ }^{132}$ At the same time, rubber was replacing other crops as the principal agricultural export, and by 1915 it replaced tin as the leading profit earner. ${ }^{133}$ With the invention of motor cars, rubber was in great demand. Malay rulers, however, failed to meet the demands due to lack of capital and labour intensive methods of mining. As a result, merchants from the Strait Settlements took over the business, resulting in increased production.

As a consequence, the British adopted an 'open door' immigration policy, bringing Chinese and Indian labour into the country to work in the mines and on the plantations. ${ }^{134} \wedge \mathrm{s}$ successful migrants, the Chinese formed shipping companies and monopolized the retail trade of the country. As early as 1907 , al-Hady warned Malays that the Chinese had already taken away almost all of their economic functions. ${ }^{135}$ The Malays during the time of al-Hady were already dependent upon the Chinese for their basic necessities. In one of al-Hady's article, he warned Malays to look around their village to see that those who sold rice, market vegetables, fish, and carried water were Chinese. ${ }^{136}$ An indication of the Chinese cconomic activity in Malaya was the amount they invested in the country. Before the war, the total amount of investment in Malaya was estimated to be $\$ 454,500,000$ and the share of the Chinese was around $\$ 200,000,000 .{ }^{137}$

The Chinese were already embroiled in political consciousness. The relaxed British policy towards Chinese in Malaya, together with the strong connection to mainland China resulted in the rise of cultural and political 
movements to garner political loyalty to China. ${ }^{138}$ When the Kuomintang (KMT) came into power in China in 1912, a wave of nationalist activism struck Malaya, creating fear among the Malays. There were already around thirty branches of KMT in Malaya during the early 1920s, whose main role was to keep the Chinese in Malaya united and in close touch with China. ${ }^{139} \mathrm{Al}$-Hady was especially angered by the Chinese who encouraged Chinese patriotism. ${ }^{140}$ In his view, the patriotic Chinese were very ungrateful to Malaya and exploited her resources, yet their loyalty was to China. The Chinese were not considered by al-Hady as the sons of the watan because they saw China as their homeland.

Although there were Chinese who did not participate in political activity and regarded Malaya as their homeland, al-Hady refused to consider them as the sons of the watan. For al-Hady, the watan was reserved for Malays. That is, those who spoke the language and knew the culture. The Chinese were perceived as others within. Such threat helped to construct the identity of the 'sons of the watan'. As for Indian migrants, al-Hady did not focus on them because of their small numbers and because many returned to India. ${ }^{141}$

The watan that was promoted by people like Abduh, Kamil and Kemal was utilized to form unity in their respective countries. Automatically, the nature of the concept was very inclusive. In other words, watan was used to bridge religious discrepancies between the inhabitants of a land so that they all could be regarded as citizens. The case with al-Hady was different. The substantial presence of immigrants who were strong economically became a threat to the Malays in the context of colonial capitalism. That is, as a community Chinese immigrants successfully worked within the capitalist system, which resulted in economic success. Watan in Malaya was conceptualized by al-Hady partly as an import from the Middle East but also as a response to its socio-political context. For al-Hady, the Chinese became a threat to the livelihood of the Malays. But it is probable that for Malays, who did not care about capitalism, the presence of the Chinese did not change anything. Seen in this way, the watan of al-Hady was very much related to the expansion of colonial capitalism to the extent that it excluded other sections of the community such as the Chinese and the Indians on the basis of race. It is here that one can notice the ambivalence in al-Hady's conception of watan, in which watan as a territorial consciousness was conceptualized to include people. Yet the watan of alHady was also tinted with ethnic categories that excluded people. The question worth asking therefore is, which one is more valued, ethnic or territorial consciousness? 
It is apparent that in the mind of al-Hady, watan was the homeland, which during his era was being colonized by the British, who usurped the authority of its original inhabitants. Watan was also seen as the highest focus of affection, duty and loyalty, which was a departure from the daula system, in which the focus was the raja. The watan was kept together by a set of laws that regulated all aspects of life, and for the introduction of law, al-Hady was thankful to the colonial powers. ${ }^{142}$ Malay monarchs automatically became part of the watan and subjected to its law. The highest glory, therefore, was not given to someone by the rajas in the form of nama, but given by the people as a result of one's service to his or her watan. From here, it is clear that the introduction of the concept of watan involved a substantial restructuring of Malay values.

Is it at this point that the territorial consciousness that was enshrined in the concept of watan became entangled with the racial consciousness of being Malay? Al-Hady himself, however, was of Haḍrāmī descent and not Indigenous Malay. He, along with his fellow editors of al-Imam, cven confessed this:

Indeed we are not of the same lineage as the people of this place, nonetheless as those who are locally born we have become attached to their country as our watan for we have drunk its milk, grown up on its flesh and blood and enjoyed all its benefits. Should we not thereforc feel indebted to its country and people? ${ }^{143}$

From this statement we can gather that al-Hady, aware of his origin, regarded Malaya as his watan as he had benefited from the land and hence, as a form of indebtedness, developed a strong affection to the land. In other words, membership of a watan was open to some who did not come from the land. But, it was possible also for some of those who had developed strong ties to the land, specifically the Chinese, to still be excluded.

The construction of 'Malay' itself is at the heart of the issuc. Malay was by no means a racial category. Rather it was a linguistic and cultural category shared by the people of the Malay-Indonesian archipelago. ${ }^{144}$ One could be Malay if one spoke the language, adapted to the customs and adhered to the religion of Islam. It is the last prerequisite, which automatically excluded the Chinese but at the same time included Hadrāmīs such as al-I Iady. In fact, the usage of Malay as a racial category began with Sir Thomas Stamford Raffles who perccived the people of the archipelago as belonging to the same race. ${ }^{145}$ The conception of Malay as a race was based on the increasing legitimacy of racial theory. It was social Darwinism and the need to justify the maintenance of direct rule in Malaya. ${ }^{146}$ It is clear, therefore, that the watan clucidated by al-Hady was a Malay watan 
reserved for the Malays not as a racial category but as a cultural-complex with religion as its cornerstone.

The last issue that we will turn our attention to is the physical manifestation of the watan. Different to Egypt, where the discourse of watan first erupted, Malaya did not consist of a single ncgeri (state). Rather, it was a constellation of different negeri ruled by different raja. Michael Laffan's observation of the translation of Mustafa Kamil's work Syams al-Mushriqa into Malay in 1906 indicated that the translation had undergone sensitization. The word wataniya (patriotism) used by Kamil was translated into anak-anak negerinya (sons of the soil). ${ }^{147}$ According to Laffan, sensitization of the translation was utilized because nationalism was an indigestible concept in the Malay world at that time and that the geopolitical nature of the Malay nation was still undefined. ${ }^{148}$ Wataniya would equate to the loyalty of the individual negeri. For that reason, it was much better to translate the word as 'inhabitants'. In 1906, watan constituted an individual negeri but not the whole Malay nation.

By 1930 , al-Hady already had in mind a Malay nationhood and its physical territory. In writing for the need for an Anglo-Malay school, al-Hady stated:

When we talk of the country of the Malays we do not mean a piece of land of only ten or one hundred acres but the whole of the peninsula and all the islands around which make up the Malay Archipelago, ${ }^{1 * 9}$

This demonstrates that al-Hady already had a clear idea of the geographical territory of the watan. It was not a negeri ruled by a raja, but the whole area that we now know as Malaysian Peninsula. What made the imagination of watan possible was the introduction and popularization of modern geography. Books such as Hikayat Dunia were published in Malaya in 1855 , which helped to conceptualize for the Malays world geography and their position within it. ${ }^{150}$ The world was not presented in terms of spiritual power over royal territory but in terms of racial and physical unity such as bangsa (nation) and tanah (soil). This together with the centralization of power in Malaya helped the Malay literati like al-Hady to imagine the physical geographical boundaries of his watan.

The popularization of watan in Malaya by modernists such as al-Hady was the second stage of the 'circumlocutory imperialism'. By this process, Western Enlightenment ideas were shrouded with Islamic ambiance and introduced to the population. The epistemological shift was facilitated by both the result of direct imperialism and indirect intellectual domination. It is important, however, to note that although al-Hady transmitted Enlightenment ideas, he was not a passive courier. Different social con- 
text forced al-Hady to reform the concept of watan from its Middle Eastern forerunner. While watan in the Middle East was an all-inclusive concept, in Malaya it became exclusive. Such remodelling of a borrowed concept can be seen as a form of subversion and disavowal of the European/ Middle Eastern concept and thus allowed al-Hady a mode of resistance. Circumlocutory Imperialism was therefore an ambiguous phenomenon, in which a site of domination simultaneously became a site of resistance.

At about the same time, there were more secularist groups in Malaya who popularized the term tanah air (land and soil) and bangsa (nation), such as Mohd. Eunos in the Malay newspaper Utusan Melayul. ${ }^{151}$ The question that should be asked is, to what extent did the imagination of watan differ to that of the more secular tanah air? And why has the latter survived until the present day while the former faded? Was al-Hady a religious thinker or did his thoughts generate the wave of secularism? Also how effective was al-Hady's campaign in Malaya? The following section is concerned with answering the aforementioned questions through the prism of his conception of watan.

\section{The Failure of Watan?}

The concept of watan proposed by al-Hady failed to produce the desired effect of social mobilization. It was debated and discussed within the public sphere but did not generate any social movements. In order to have a mobilizing effect, an idea must connect itself to its social context. ${ }^{152}$ The social context in which watan was positioned did not favour its implementation. A strong feudal system, robust traditional religious authority and the resistance of the population impeded the realization of his innovation. In this section we examine al-Hady's attitude towards the traditional religious establishment, especially to the dominant practice of Sufism, relating it to his conceptualization of watan. In addition, al-Hady's cffort in building the new social context is also dealt with. From this we can assess al-Hady's endeavours and diagnose the causes of his failure. The final part looks at the continuity and change of Malay national imagination.

Islam came to the Indo-Malay archipelago through the preaching of the Sufis. It was the specific nature of Sufism which, according to A.H. Johns, facilitated the absorption of non-Muslim communities into the fold of Islam. ${ }^{153}$ Sufism in Malaya worked within the tight compound of the shar' ${ }^{\prime}$ ah 'and became the popular religious norm in the region. To talk about Islam in Southeast Asia, therefore, is to talk about Sufism.

The introduction of new concepts and key-terminologies by Sufis altered the traditional Malay worldview into an Islamic one. ${ }^{154}$ In particular, the Malays became accustomed to Islamic metaphysics and epistemology 
thorough the spread of Sufi literature in the region. The oldest known Malay manuscript, for instance, the $16^{\text {th }}$ century translation of the $A q \bar{a}^{\text {' }}$ id of an-Nasafi, was a work of theology with an exceptional focus on the problem of knowledge. ${ }^{155}$ The Malay translation of the Ihyā 'Ulüm al-Dinn, ${ }^{156}$ the Sufi canon in which al-Ghazali devoted the first section to the theory of knowledge, was studied by the disciples of Sufism throughout the archipelago ${ }^{157}$ As guardian of Islamic epistemology, the Sufis were hostile to the incursion of modern Western ideas, which entailed secularism, into the Malay world. ${ }^{158}$ They were also hostile to Muslims who advocated the idea of Islamic modernism. There was an incident reported in al-Ikhwan where some traditional religious leaders claimed that killing the Kaum Muda was permissible. ${ }^{159}$ The Sufi presence proved to be an obstacle to al-Hady.

Al-Hady addressed the differences in ideas between himself and the Sufis. He ridiculed the Sufis by saying:

No doubt those who fondle and count their tasbihs [rosaries], or those who sell the words of the Qur'an as amulets, or those who twist the minds of women, will condemn me vehemently and in the worst language, but I care not as long as I am appealing with the call of the Qur'an. ${ }^{160}$

There is no doubt that it was the Sufis that al-Hady was referring to with the words 'those who fondle and count their tasbihs'. The other two characteristics, however, resemble moreso Malay sorcerers ${ }^{161}$ who, although influenced by animistic practices, were treated tolerantly by traditional Muslim scholars. They were given protection and food as long as they behaved in accordance with Islamic virtues and in return they let Islam affect their practices and techniques. ${ }^{162}$ Qur'anic texts, the Names of God and the Prophet, for example, were used in their spells and amulets. ${ }^{163}$

The fact that al-Hady classified magicians and Sufis in the same category suggests that his view of the traditional religious establishment was dominated by colonial representations. Magic, amulets and Sufi orders were seen as powerful exotic phenomena, which created colonial anxieties. ${ }^{164} \mathrm{~A}$ perfect example of this was the incident in Garut, West Java in 1919 when Haji Hasan, a farmer, disobeyed colonial farming policy. When approached by the authorities, Hasan entered his house, closed all doors and windows and started Sufi chanting with his family. The colonial authorities decided to attack, killing Hasan and his family because they thought that Hasan was a sorcerer with potent spiritual power. ${ }^{165}$ This incident shows how fearful the colonial authorities were towards amulets and magic. The colonial representation of Hasan blended Sufism and magic together. The two different phenomena were seen 
as one by the colonial eye: a foreign, mysterious and dangerous threat to the colonial state. Al-Hady, in mixing Sufism and magic had re-presented colonial representations, and therefore secured his own active position within the colonial discourse.

Al-Hady attacked the Sufis for their overemphasis on the eschatological aspects of Islam, which he felt led people from their worldly responsibilities. In fact, in Kitab Ugama Islam dan Akal, al-Hady maintained that the real purpose of imposing the five rituals in Islam was to serve the development of the individual Muslim and his welfare as well as the needs of Muslim society. ${ }^{166}$ For al-Hady, any form of worship, which did not have practical social virtues and benefits to the community should not be followed. The Sufis, in stark contrast, affirmed the centrality of spirituality in worship and religious acts. Al-Hady, therefore, connected the religious acts of worship with the fulfilment of modern society as depicted in his conception of watan.

For al-Hady, worldly progress was the true calling of Islam. In a stronger sense, al-Hady accused the traditional religious 'ulamä' of having lost 'all ability to understand the true calling of their sublime religion' ${ }^{167}$ As a result, Islam 'has lost its original identity and purpose' ${ }^{168} \mathrm{Al}-\mathrm{Hady}$ boasted of the progress of Islam as a religion which would create the greatest community on earth, as "countries which had come under Islam were prosperous and advanced'. ${ }^{169}$ Here al-Hady employed history to illustrate his point. The history he alluded to, however, was very much his own modern construction. For instancc, in defending the right of women to become leaders, al-Hady used the historical events of the early years of Islam in which the widow of the Prophet, "Așshah led a rebellion against the caliph 'Alī ibn Abi TTălib, which resulted in the outbreak of the first civil war of the lslamic history. ${ }^{170}$ In al-Hady's view, this event shows how in the early years of Islam, women could take active part in politics and warfare. ${ }^{171}$ For traditionalists, the incident supported their argument that women should not lead as it would generate civil war.

Modernists like al-Hady were pressured to ncutralize the colonial and missionary representation of Islamic history, which painted it as inferior, feminine and passive. Such representation can be seen broadly in the range of fictional stories written about the Malays. ${ }^{172}$ For that reason, the past was modernized, authenticated and rationalized in order to obliterate the prevalent representation. ${ }^{173}$ In addition, the constructed past, which presented Islam as a nation not a religion, was remembered for its political, cconomic, social and scientific progress as opposed to its spiritual significance. $\mathrm{Al}$-Hady surveyed the religion and its history through the trajecto- 
ry of his own conception of watan, that is, of nationhood and secular progress.

Al-Hady did not only attack the 'ulamă' but also their power-base, the religious educational institutions. By the Eighteenth century, pondok[s] (Islamic boarding school) became the venue in which the study of Islamic mysticism was taught. ${ }^{174}$ The relationship between the teachers and the pupils in the pondok was based on the sufistic master-disciple relationship. The surau (small mosque) also became an important centre for mystical education. ${ }^{175} \mathrm{Al}-\mathrm{Hady}$ criticized the students of the pondok for practicing what the Prophet did not instruct them to do. ${ }^{176}$ Such associations did not bring any 'benefit to the Muslim community or to the country in accordance with the commandments and requirements of Islam'. ${ }^{177}$ Again, al-Hady connected Islam to the concept of community and country. Education which was aimed at the betterment of the individual changed to be focused on the improvement of the watan. Al-Hady developed his own alternative to traditional education.

Al-Hady's attack on the traditional 'ulamā' and Sufis did not produce the desired effect of mobilizing the masses. The majority of the Malays adhered to the traditional religious values and it tended to be only the Malays from urban centres who supported al-Hady's ideology. Malays in general actively resisted the importation of modern religious values into their society by refusing to support al-Hady's foreign ideas. Elitism and alienation of the population from Islamic modernist idcas was a systemic and broader problem in the Muslim world, which led to the failure of the modernizing project.

As a modernist, it was not enough for al-Hady to attack the traditional religious establishments and their worldview; he also had to provide an alternative. It was therefore critical for al-Hady to develop a context that would facilitate the emergence of an educated Malay middle class. Through the publication of journals and newspapers, al-Hady attempted to build the social context in which his ideas could be reccived. He did not want the journals to be elitist, but rather a mass endeavour. In one editorial piece in Saudara, for example, al-Hady reiterated his views on the aims of newspaper. He stressed that articles should be precise and written in simple language. ${ }^{178}$ In addition, long articles should be divided into parts so as not to bore readers. ${ }^{179} \mathrm{According}$ to a friend of al-Hady, Za'ba, Malay journalism in the early twentieth century was not only to supply news and information, but new ideas and to instigate public debates. ${ }^{180}$ Throughout the towns and villages, Za'ba could see people clustering together in coffee shops debating the latest articles in the newspaper. ${ }^{181} \mathrm{Al}$-Hady seemed to notice the effectiveness of nowspapers and for that reason he utilized them ac- 
cordingly. It is clear that al-Hady saw the newspaper as a mass medium that should not be reduced to elitist circles, but to be used to instigate social changes including moving to a more modern society where his ideas could flourish.

In his novels he created conditions in which his ideas were implemented in daily lives. Virginia Hooker asserted that in his novels, al-Hady presented the functionality of his modern ideas thorough the characters involved. ${ }^{182}$ So, while in his non-fictional works al-Hady provided theories, in his novels he presented 'living' examples. Despite the popularity of the novels, it is difficult to gauge their reception. ${ }^{183}$

Another way of providing an alternative social context was through the establishment of modern educational institutions. Al-Hady founded three modern madrasahs in Singapore, Malacca and Penang. Here, Arabic and basic lslamic sciences were taught alongside other sciences and English. ${ }^{184}$ Al-Hady's intention was to found an educational institution to produce Malays who were well-versed in religion as well as secular sciences. The plan failed because of entanglement with politics, opposition from the traditional religious establishments, lack of qualified teachers and funds. The pondok $[\mathrm{s}$ ] were more thorough in their instruction of religion while the secular schools were more advanced in their teaching of non-Islamic scicnces. Modern madrasahs were in a state of limbo between the two. Towards the end of his life, al-Hady seemed to have become disillusioned with the madrasah. ${ }^{185}$

In 1930, al-Hady published his proposal for the establishment of an Anglo-Malay school with English as the language of instruction. ${ }^{186}$ According to al-Hady, 'other than an English-language school, there is no other educational institution'. ${ }^{187}$ His hope was that the qualification of the school could be recognized by the government. Al-Hady's desire for an Anglo-Malay school was highly utilitarian: he feared that the Malays would be crushed if they could not master the administrator's language. Ultimately, he wanted some educated Malays to participate in the colonization of other Malays.

Education was one of the most significant tools used by imperial powers to secure their rule. Lord Macaulay, for instance, addressed the need to form a class 'Indian in blood and colour, but English in taste, in opinions, in morals and in intellect. ${ }^{188}$ English education was used to form a middle class that could act as interlocutor between the colonizers and the colonized. British colonial administrators utilized English literature as a tool to control natives under the guise of liberal education. ${ }^{189}$ To be able to work in the administration, fluency in English was required. To use Gram- 
schi's words, 'cultural domination [operated] by consent'. ${ }^{190}$ Through education the colonizer maintained control over the consenting colonized.

With his proposal for the establishment of an Anglo-Malay school, alHady played an important role within the colonial agenda of dominating the colonized. According to Frederick Cooper and Ann Stoler, colonialism was marked by the collaboration between the colonizers and the colonized, the metropole and the periphery. ${ }^{191}$ The colonial educational agenda would not have succeeded had the colonized themselves not welcomed it. It was individuals like al-Hady who acted as the interlocutor for the colonial project. This can be seen where he said:

When an indigenous people have education comparable to that of the invaders, follow the way these intruders educate their children, venture into any industry and profession, use the same shield in the battle of life, then surely they would survive and compete with the foreigners. ${ }^{192}$

Al-Hady's argument was not unlike that of Lord Macaulay's; al-Hady was striving for people who were Malay in blood and flesh but English in their way of life.

\section{Watan and Bangsa}

During al-Hady's time, another political consciousness was developing - the bangsa consciousness popularized by Mohd. Eunos Abdullah in his periodical, Utusan Mclayu. ${ }^{193}$ The periodical has been described as the 'liberal critique of the kerajaan'. ${ }^{194}$ Eunos was representative of liberallyeducated Malays, who were more secular in their outlooks than the Islamic oriented al-Imam group. Bangsa consciousness, in the mind of Eunos, was a Malay racial consciousness which was conceptualized during the times of increased migration to Malaya. ${ }^{195}$ According to Ariffin Omar, Eunos' conception of bangsa was somewhat more exclusive than al-Hady's watan as Eunos limited Malayness to those who had Malay descent, thereby excluding the Arabs. ${ }^{196}$ This meant a Malay of Arab descent, likc al-Hady, was not Malay. Ariffin's assertion is problematic because al-Hady supported Eunos. In an article written on the establishment of a Malay organization in Singapore headed by Eunos, al-I lady praised the effort of "sahabat kita yang dikasihi' (our beloved companion) in educating the Malays to act for the betterment of the bangsa. ${ }^{197}$ This suggests that there was no conflict between the bangsa of Eunos and the watan of al-Hady. By using the word bangsa, al-Hady himself was supportive of Eunos' concept. The bangsa of Eunos was territorial and cultural, not racial as Ariffin portrayed. 
The successors of Eunos were more extreme. Abdul Rahim Kajai, for instance, explicitly excluded Arabs and Indian Muslims from the Malay circle. ${ }^{198}$ Under the fear of Chinese political activism in Malaya, the more racial bangsa gained currency within the autochthonous Malay intelligentsia. Malaya, in their view, was solely for Malays. Chinese or other ethnic communities did not have the right to participate in the country's politics. The successors of the kaum muda, in contrast, argued for a territorial consciousness for the inhabitants of Malaya, which included the Chinese, Arabs and Indians. When the British, after the war, planned to set up a Malayan union which aimed to integrate the Chinese and the Indians into one Malayan polity, the bangsa-minded Malays led by the traditional aristocrats jeopardized it. ${ }^{199}$ Since that day, the bangsa consciousness remains the central force of Malay nationalism.

The aristocrats who led the struggle for bangsa-mindedness formed the United Malay Nation Organization (UMNO), which became the primary political vehicle for Malays. In contrast to al-Ilady, the aristocrats successfully mobilized the masses by utilizing the traditional structures within the Malay community. ${ }^{200}$ Al-Hady failed to mobilize people because his project was elitist in nature and did not incorporate traditional structures. The words of Frantz Fanon encapsulate this phenomenon:

Now it so happens that during the struggle for liberation, at the moment that the native intellectual comes into touch again with his people, this artificial sentinel is turned into dust. $\Lambda \mathrm{ll}$ the Mediterranean values the triumph of the human individual, of clarity and of beauty - become lifeless, colourless knick-knacks. ${ }^{201}$

In the end, racial consciousness became the predominant national awareness in Malaya and relations between Malays and other ethnic groups remained problematic. The state, Malaysia, came to exist as a result of what T.N. Harper described as the dialectic of late-colonialism, when the British engagement in Malaya was satisfactorily concluded. ${ }^{202}$ What was left was to transfer the state to those who could safeguard British interests in the region. The result was a nation-state based on political pragmatism. Racial tensions were suppressed by the state, resulting in ethnic tensions and communalism which remain unresolved today. ${ }^{20.3}$ Nationalism that incorporates what we know as "Malaysians" is still in the process of being defined. 


\section{Conclusion}

\section{J. Farish said in 1838:}

The Natives must either be kept down by a sense of our power, or they must willingly submit from a conviction that we are wiser, more just, more humane, and more anxious to improve their condition than any other rulers they could have. ${ }^{234}$

Although he was actually speaking here of India, he could very well have said the same thing correctly of Malaya.

By examining his conception of watan - a term that has been taken for granted by previous writers on al-Hady — we can detect that al-Hady's social, economic, religious and educational reform agenda was ultimately part of his strive for a national consciousness distinct from that of the kerajaan. To a large extent, al-Hady was not as 'Islamic' as he has been presented by historians. For instance, Roff demonstrated that kaum muda's first concern was with religion, ${ }^{205}$ while Radin Socnarno indicated that al-Hady was an important supplier of Islamic impulses in Malay politics. ${ }^{206}$ While many of his ideas came from European Enlightenment ideology in Egypt, al-Hady presented them in Islamic fashion to gain Malay support. The Islamic facade utilized by al-Hady convinced many historians of his intense religiosity,

As this study has shown, however, the religiosity preached by alHady was of a different nature to the traditional Islamic teachings: it was a product of the colonial encounter. Islam was held merely as a set of logical justifications for modernity. Although the use of Islamic jargon persisted, this was merely a tool utilized by al-Hady to popularize his ideas a phenomenon that Fazlur Rahman described as a 'janus-faced attitude'. ${ }^{207}$ Al-Hady utilized the Islamic facade to further his own modern agenda, that of supplanting the kerajaan with a European notion of territorial nationalism. He celebrated the presence of the British as an alternative to the traditional polity. $\mathrm{Al}-\mathrm{Hady}$ therefore served as a testimony to the colonial program, with the conviction that the British were "more anxious to improve their condition than any other rulers they could have'. ${ }^{208}$

By accepting the foundation of Western epistemology, al-Hady carried with him an integral part of Enlightenment thought: secularization. He fulfilled the three components of sccularization, which enabled him to reshape the Malay worldview into that which was applicable to modernity. By wanting the Malays to be industrious and urging the transformation of the wilderness into plantations, al-Hady stressed the 'disenchantment of nature by secing nature as an economic commodity. By attacking the kerajaan and presenting it as a body-politics responsible to the watan, he desacrilized politics, thereby shattering the mystical justification of the 
polity. Finally by turning education into a utilitarian endeavour for the betterment of the watan and by calling Malays to participate in colonial capitalism, al-Hady deconsecrated the traditional value-system of the Malays. By al-Attas' definition, al-Hady was an agent of the secularization of Malay worldview.

This brings us to the theoretical contribution of this article to the ongoing debate of the relationship between Islam and modernity. The recent phenomenon of Islamic terrorism has directed the gaze of the world on Islam. The pressure from Western powers to adapt Islam to a more reconciliatory attitude towards the West and 'modernity' has produced a diverse range of literary responses. ${ }^{209}$ In Indonesia, for instance, emerging proponents of 'liberal Islam' clashed with the traditional religious establishments in their attempt to re-mould Islam to conform to Western liberal democracy. ${ }^{210}$ The intellectual debates taking place within the Muslim community, however, should be examined within the context of Western dominance in the global political, economic and military arenas.

Being aware of the global context in which this article is written, I embarked on a study of Islamic modernism at the beginning of the $20^{\text {th }}$ century. This study sought to locate the modernist thoughts of al-Hady within the wider context of the prevalent global power structure of the time. By doing so, we can see how his thoughts were a product of the colonial encounter, they were an attempt to recreate and adjust the Muslim world in light of 'Western perfection'. The economic and military might of Europe paved the way for the birth of 'liberally' reformed Islamic thoughts that justified the power structure while simultaneously attempting to imitate 'mighty Europe'.

I define circumlocutory imperialism as the intellectual domination and subjugation of one group by another as a result of imperialism in the economic and military realms that have happened through a third agent or location. This theory is by no means a general theory, rather, it is specific to the phenomenon of Islamic modernism in Malaya. While on the specific level of Malayan history, the theory has opened a new way of examining al-Hady, on the broader level it creates another theoretical construction of the post-colonial issue of intellectual imperialism and dependency.

It is important, however, not to see al-Hady as a passive receiver of Enlightenment ideas. Circumlocutory imperialism was by no means a stable and uniformed relationship but one full of contradictions and ambivalence that acted as a site of subversion and resistance. As Shakespeare wrote: 'You taught me language, and my profit on't is I know how to curse'211 When Caliban utters these words to Prospero, he is transforming an act of cultural imperialism into a site of resistance. Caliban was taught 
by his master to speak, think and act in a civilized European manner and yet that ability was distorted to produce an unacceptable form of speech. Using the 'refined' language of the colonizers and yet altering it to fit one's position is a form of subversion to the colonial power.

Through examining the concept of watan in al-Hady's thoughts we observe a similar phenomenon. Watan was an Enlightenment concept taken from Europe through Egypt. Yet when it came to Malaya, it was no longer the all-inclusive territorial consciousness but one that had been infused with cultural and religious elements. In contrast to European patriotism, the watan of al-Hady was reserved for Malays alone, excluding the Chinese. This was, therefore, a subversion and disavowal of the European concept and thus allowed al-Hady a mode of resistance. Circumlocutory imperialism therefore, was a process of intellectual domination, but one which also generated agency of the dominated to resist; creating both sites of domination as well as resistance. 


\section{Endnotes}

* This article is based on the author's Honours thesis entitled 'Circurnlocutory Imperialism: A study on the Concept of Watan in the Thoughts of Syed Shaikh bin Ahmad al-Hady' submitted to the History Department, University of Melbourne, 2005. The author would like to acknowledge the tremendous help during the writing of the thesis and its subsequent publication to Dr. Nicole Tarulevicz, Associate Professor Syed Farid Alatas, Professor Azyumardi Azra, Associate Professor Antonia Finnane and Dr. Oman Fathurahman.

1. This article is based on the author's Honours thesis entitled 'Circumlocutory Imperialism: A study on the Concept of Watan in the Thoughts of Syed Shaikh bin Ahmad al-Hady' submitted to the History Department, University of Melbourne, 2005. The author would like to acknowledge the tremendous help during the writing of the thesis and its subsequent publication to Dr. Nicole Tarulevicz, Associate Professor Syed Farid Alatas, Professor Azyumardi Azra, Associate Professor Antonia Finnane and Dr. Oman Fathurahman.

2. Ismail F. Alatas received his Bachelor of Arts with Honours majoring in history from the University of Melbourne, Australia.

3. Hussin Mutalib, "Islamic Malay Polity in Southeast Asia" in Islamic Civilization in the Malay World, ed. Mohd. Taib Osman (Kuala Lumpur: Dewan Bahasa dan Pustaka, 1997), 47.

See also: Mohd. Nor Bin Ngah, "Islamic World-view of Man, Socicty and Nature among the Malays in Malaysia," in Malaysian World-View, ed. Mohd. Taib Osman (Singapore: Institute of Asian Studies, 1985), 33.

4. A.C. Milner, Kerajaan: Malay Politcal Culture on the Lve of Colonial Rule (Tucson: University of Arizona Press, 1982), 113.

5. Mohd. Taib Osman, "The Traditional Malay Socio-Political World-View", in Malaysian World-View, ed. Mohd. Taib Osman (Singapore: Institute of Asian Studies, 1985 ) 66.

6. Hussin Mutalib, "Islamic Malay Polity in Southeast Asia", 18; A.C. Milner, Kerajaan, 9. Also S. M. Naquib Al-Altas, "Appendix: On Islamization: The Case of the MalayIndonesian Archipelago" in Islam and Secularism (Kuala Lumpur: ISTAC, 1993) 177. In the view of al- $\Lambda$ ttas, Islam was the unifying factor throughout the Malay world.

7. Anthony Reid, "Understanding Melayu (Malay) As a source of diverse modern identities", Journal of Southeast Asian Studies, 32, 3 (2001): 295-313; Richard Winstedt, The Malays: A Cultural History (London: Routledge \& Kegan Paul, 1961), 35-44.

8. Seyyed Hossein Nasr, Traditional Islam in the Modern World, quoted in Joseph E.B. Lumbard, "Introduction," in Islam, Fundamentalism, and the Betrayal of Tradition, ed. Joseph E.B. Lumbard, (Bloomington: World Wisdom, 2004), xiii.

9. Sayid Muhammad Ahmad Assyathiri, "Muqaddimah" in Siräh as-Salāf min Banṣ 'Alāwīy Al-Husainiȳn (Jeddah: 'Alam al-Ma'rifah, 1405H).

10. J. A. E. Morley, "The Arabs and the Eastern Trade", JMBRAS 22, 1 (1949): 143-76.

11. Mahayudin IIaji Yahaya, "Latarbclakang Sejarah Keturunan Sayid di Malaysia" in Tamadun Di Malaysia, ed. Khoo Kay Kim (Kuala Lumpur: Persatuan Sejarah Malaysia, 1980), 66.

12. R. O. Winstedt, "A History of Malay Literature," JMBRAS 17, 3 (1939), 131.

13. Jamilah Othman, Sayyid Syakh al-Hadi, His Role in the Transformation of Mustim Societies in Peninsular Malaya and the Straits Settlements during the Latter Half of the Nineteenth and Early Twentielh Centuries (M.A. Thesis, University of Malaya, 1979), 35.

14. Abu Hassan Sham, "Tariqat Naqsyabandiyah dan Peranannya dalam Kerajaan Melayu Riau sehingga Awal Abad Kedua Puluh", in Tamadun Islam di Malaysia, cd. Khoo Kay Kim (Kuala Lumpur: Persatuan Sejarah Malaysia, 1980), 74-86.

15. Mona Abaza, Islamic Education: Perception and Exchanges, Indonesian Students in Cairo (Paris: Association Archipel, 1994), 55. See also: William R. Roff, "Indonesian and Malay Students in Cairo in the 1920s", Indonesia 9 (1970), 73-87; Michael $F$. Laffan, Islamic Nationhood and Colonial Indonesia: The Umma beneath the Winds (London: RoutledgeCurzon, 2003), 127-131; 136-141. 
16. Linda Tan, "Syed Shaykh: His Life and Times" in The Real Cry of Syed Shaykh alHady, ed. Alijah Gordon (Kuala Lupur: MSRI, 1999), 110.

17. According to Roff, al-Inam was published monthly in Singapore between 22 July 1906 to 25 December 1908. See: William R. Roff, Bibliography of Malay and Arabic Periodicals Published in the Strait Settlements and Peninsular Malay States 18761941 (London: Oxford University Press, 1972), 31.

18. For information on Syaikh Tahir Jalaluddin see: Abu Bakar Hamzah, "Sheikh Tahir Jalalu'ddin", Medium 1 (1988), 88-95.

19. Syed Alwi al-Hady, "The Life of My Father", in The Real Cry of Syed Shaykh al-Hadi, ed. Alijah Gordon (Kuala Lumpur: MSRI, 1999), 79.

20. Ibid., 128.

21. Ibid., 129. See also: Linda Tan, "Syed Shaykh: His Life and Times", 129.

22. Ibrahim Abu Bakar, Islamic Modernism in Malaya: The Life and Thought of Sayid Syekh al-Hadi, 1867-1934 (Kuala Lumpur: University of Malaya Press, 1994), 71.

23. Syed Alwi al-Ilady, "The Life of My Father," 79.

24. Ibid., 79. See also: Khoo Kay Kim, "Malay Society, 1874-1920s", Joumal of Southcast Asian Studies V, 2 (1974): 197.

25. Sohaimi Abdul Aziz, "Pengenalan" in Syed Syeikh al-Hadi: Cendekia dan Sasterawan Ulung, ed. Sohaimi Abdul Aziz (Pulau Pinang: Penerbit Universiti Sains Malaysia, 2003), 1.

26. Al-Ikhwan wad published monthly in Penang: between 16 September 1926 and December 1931. Saudara was published weekly in Penang between 29 September 1928 and 1941. See: Roff, Bibliography of Malay and Arabic Periodicals, 40, 41.

27. Works written during this period were: Hikayat Faridah Hanom (Kuala Lumpur: Pustaka Antara, 1964); Hikayat Taman Cinta Berahi (Pulau Pinang: Jelutong Press, 1927); Hikayat Puteri Nurul Ain (Pulau Pinang: Jelutong Press, 1928).

28. Works written during this period were: Al-Tarikh al-Islami (Pulai Pinang: Marcantile Press, 1922); Tafsir al-Fatihah (Pulau Pinang: Jclutong Press, 1928); Kitab Agama Islam dan Akal (Kota Bharu: Pustaka Dian, 1965); Kitab Alam Perempuan (Pulau Pinang: Jelutong Press, 1930).

29. For the life of al-Hady, see Appendix A.

30. Syed Alwi al-Hady, "The Life of My Father", 79.

31. Sohaimi Abdul Aziz, "Pengenalan", 1.

32. For the life and thoughts of Abduh see: Yvonne Haddad, "Muhammad " $A$ bduh: Pioneer of Islamic Reform", in Ali Rahnama (ed.) Pioneers of Islamic Revival (London: Zed Books, 1994), 30-63.

33. Syed Hussein Alatas, "Academic Imperialism" in Reflection on Alternative Discourse from Southeast Asia: Proceedings of the ISA Regional Conference for Southeast Asia, Singaporc 30 May-1 June 1998, ed. Syed Farid Alatas (Singapore: Pagesetters Service, 2001) 32 .

34. Syed Hussein Alatas, "Academic Imperialism", 33.

35. Syed Muhammad Naquib al-Attas, Islam and Secularism (Kuala Lumpur: ISTAC, 1993), 17. al- $\Lambda$ ttas derived the definition from the Dutch theologian Cornclis van Peursen and the Harvard theologian, Harvey Cox. For more information, sec: Harvey Cox, The Secular City (London: SCM Press, 1966).

36. Syed Muhammad Naquib al-Attas, Islam and Secularism, 18.

37. Michael F. Laffan, Islamic Nationhood in Colonial Indonesia, 149.

38. Yvonne Haddad, "Muhammad Abduh", 30-63.

39. Kenneth Cragg, "Religious Development in Islam in the 20 th Century", Cahiers d'Histoire Mondiale 3, 2 (1974): 504-24.

40. Charles Kurzman, "Liberal Islam and its Islamic Context", in Liberal Islam: $A$ Sourcebook, ed. Charles Kurzman (Oxford: Oxford University Press, 1998), 9.

41. Jutta E. Bluhm, "Preliminary Statement on the Dialoguc Established Between the Reform Magazine al-Manar and the Melayo-Indonesian World", Indoncsian Circle 32 (1983): $35-42$. 
42. In the words of Za'ba, 'the Malays take the worst thing if it is brought to them in the name of Islam', see: Za'ba, "The Malays and Religion", in Khoo Kay Kim (Ed.) Tamadun Islam di Malaysia (Kuala Lumpur: Persatuan Sejarah Malaysia, 1980), 10312.

43. Fazlur Rahman, "Islamic Modernism: Its Scope, Method and Alternatives," International Journal of Middle East Studies I, 4 (1970): 323.

44. Bassam Tibi, "Islam and Modern European Idcologies," International Journal of Middle East Studies 18, 1 (1986): 15-29.

45. Azyumardi Azra, The Origins of Islamic Reformism in Southeast Asia: Networks of Malay-Indonesian and Middle Eastern 'Ulama' in the Seventeenth and Eighteonth Centuries (Crows Nest : Allen \& Unwin, 2004).

46. Partha Chaterjee, Nationalist Thought and the Colonial World: A Derivative Discourse? (New Delhi: Zed Books, 1985), 11.

47. Bernard Lewis, "Watan," Journal of Contemporary History 26, 3/4 (1991): 525.

48. Ibn Mandzur, Lisän al-'Arab (Beirut: Dar al-Ihya' wa al-Turath al-Arabi, 1997), 15; 338.

49. Edward William Lane, Arabic-English Lexicon (New York: Frederick Ungar Publishing, 1956) book. 1, part 8,3056

50. Ali bin Muhammad al-Jurjani, Kitâb at-Ta'rşăt (Cairo: Dar al-Irshad, 1991), 281.

51. Lewis, "Watan", 525.

52. Muhammad Asad, The Message of the Quran (Gibraltar: Dar al-Andalus, 1980), 177.

53. Holy Qur'an, translated by A. Yusuf Ali (n.p.: Islamic Propagation Centre International, 1946) $10: 19$

54. Abdullah al-Ahsan, Ummah or Nation? Identity Crisis in Contemporary Muslim Socicty (Lciccster: The Islamic Foundation, 1992), 18-19.

55. See: Seyyed Hossein Nasr, Islam: Religion, History and Civilization (Surabaya: Risalah Gusti, 2003), 137-141.

56. See: A.A. Duri, The Historical Formation of the Arab Nation, translated by Lawrence I. Conrad (Iondon: Croom Helm, 1987), 326, Karen Armstrong, Islam: A Short History (London: Phoenix Press, 2000), 69-79.

57. al-Ahsan, Ummah or Nation?, 24.

58. Antony Black, The History of Islamic Political Thought: From the Prophet to the Present (Edinburgh: Edinburgh University Press, 2001), 50-1,

59. Ibid.

60. Intti, History of the Arabs (Jakarta: Serambi, 2005), 924-5.

61. Albert Hourani, Arabic Thought in the Liberal Age, translated by Suparno (Bandung: Mizan, 2004), 113.

62. William L. Cleveland, A History of the Modem Middle East, second cdition (Boulder: Westvicw Press, 2000), 66.

63. Azzam S. Tamimi, "The Renaissance of Islam", Dedalus 132, 3 (2003): 52.

64. Bassam Tibi, Arab Nationalism: A Critical Inquiry, second edition (London: Macmillan, 1990), 85. For biographical notes, see: J. Heyworth-Dunne, "Rifa'a Bey Rafi" alTahtawi", Bulletin of the School of Oriental and African Studies IX (1937/39): 9617.

65. Mohammed Sawaie, "Rifa'a Rafi Al-Tahtawi and his contribution to the lexical development of modern literary Arabic," International Joumal of Middlc East Studics $43,3(2000): 395$.

66. Ibid., 87.

67. Khaldun S. al-Husry, Three Reformers, A Study in Modern Arab Political Thought (Beirut: Khayats, 1966), 29.

68. A.A. Duri, The Historical Formation of the Arab Nation, 156. See also: Charles Wendell, The Evolution of the Egyptian National Image: From Its Origins to Ahmad Lutfi al-Sayyid (Berkeley: University of California Press, 1972), 129-30.

69. Cleveland, A History of Modern Middle East, 78-9. 
70. Fatma M. Gúcck, The Rise of the Bourgeoisic, Demise of Empire - Ottoman: Westernisation and Social Change (Oxford: Oxford University Press, 1996).

71. For an overview of the political reform, sec: Robert Devereux, The First Ottoman Constitutional Period; a Study of the Midhat Constitution and Parfiament (Baltimore: Johns Hopkins, 1963).

72. Bernard Lewis, The Emergence of Modern Turkey (London: Oxford University Press, 1961), 125 .

73. Serif Mardin, The Genesis of Young Ottoman Thought: A Study in the Modemization of Turkish Political Ideas (Syracuse: Syracuse University Press, 2000), 327.

74. Ernest Renan, "What is a Nation?" in Becoming National: A Reader, eds. Geoff Elcy \& Ronald Grigor Suny (New York: Oxford University Press, 1996), 41-55.

75. Ibid.

76. Lewis, Emergence of Modern Turkey, 140.

77. al-Ahsan, Ummah or Nation?, 35.

78. Nermin Menemencioglu, "The Ottoman Theatre, 1839-1923", Bulletin 10, 1. (1983): 53.

79. Mardin, Genesis of Young Ottoman, 330

80. For the biography of Jamaluddin al-Afghani, see: Nikki R. Keddie, An Islamic Response to Impcrialism: Political and Religious Writings of Sayyid Jamal al-Din al-Afghani (Berkeley: University of California Press, 1983).

81. Elie Kedourie, Afghani and 'Abduh: An Lssay on Religious Unbelief and Political Activism in Modern Islam (London: Frank Cass, 1966), 63.

82. Nikki R. Keddie, "Pan-Islam as Proto-Nationalism", The Journal of Modern History 41, 1 (1969): 11.

83. M.A. Zaki Badawi, The Reformers of Egypt (London: Croom Helm, 1978), 22.

84. Quoted in Duri, Historical Formation of the Arab Nation, 157.

85. Quoted in Zaki Badawi, Reformers of Egypt, 42.

86. For the treatment of Dhimmis, see the work of the 8th century Muslim jurist: $A b u$ Yusuf Ya'qub, Kitab al-Kharaj (Beirut: Dar al-Ma'rifah, 1979).

87. Nadav Saffran, Egypt in Scarch of Political Community: An Analysis of the Intellectual and Political Evolution of Egypt, 1804-1952 (Cambridge: Harvard University Press, 1981), 71.

88. Albert Hourani, Arabic Thoughts, 220-57.

89. Ibid., 254.

90. 1bid., 321 .

91. Ibid, 324-5.

92. Hisham Sharabi, Arab Intellectuals and the West: the Formative Year, 1875-1914 (Baltimore: Johns Hopkins Press, 1970), 105-128.

93. Edward Shils, "Intellectuals", in The Intellectuals and the Powers and Other Essays (Chicago, University of Chicago Press, 1972).

94. David E. Apter, The Politics of Modernization (Chicago: University of Chicago Press, 1965), 268.

95. A.L. Tibawi, "From Islam to Arab Nationalism", Arabic and Islamic Themes: Historical, Educational and Literary Studies (London: Luzac \& Company, 1976), 109.

96. Talal Asad, Formations of the Secular: Christianity, Islam and Modernity (Stanford: Stanford University Press, 2003), 181-201.

97. Linda Tan, "Syed Shaykh", 110. Works of Abduh, translated by al-Hady were for instance: Sycd Syaikh al-Hady, Tafsir al-Fathah.

98. For instance, writers like: William Roff, The Origins of Malay Nationalism (Kuala Lumpur: University of Malaya Press, 1967); Anthony Milner, The Invention of Politics in Colonial Malaya (Cambridge University Press, 2000); and Abdul Aziz Mat Ton, Politik al-Imam (Kuala Lumpur: Dewan Bahasa \& Pustaka, 2001).

99. Homi Bhabha, "Of Mimicry and Man: The Ambivalence of Colonial Discourse" in Tension of Empire: Colonial Cultures in a Bourgeois World, eds Frederick Cooper \& Ann Laura Stoler (Berkelcy: University of California Press, 1997), 152-160. The concept of 'ambivalence' is also discussed in Homi Bhabha, The Location of Culture (London; Routledge, 1994), 85-92. 
100. Shaharuddin Maaruf. Malay Ideas on Development: From Feudal Lord to Capitalist (Singapore: Times Book International, 1988), 44-5.

101. Syed Shaykh al-IIady, "Teguran dan Jawaban-nya", al-Ikhwan I, 3 (16 November 1926), this article also reproduced in Abdullah Hussain \& Khalid Hussain, Pendita Zaaba Dalam Kenangan (Kuala Lumpur: Dewan Bahasa dan Pustaka, 1974), 231-7.

102. Ibid. The Qur'anic verse was taken from Surah XXI: 105.

103. Syed Syakh al-Hady, "Ulama' di Kelantan dengan al-Ikhwan dan Saudara", al-Ikhwan III, 7 (16 March 1929).

104. al-Hady, "Ada-kah Kaum Melayu ini Dapat Melepaskan Wujud-nya daripada Fana dan Hapus? Apakah penyakit ketcwasan semua kaum Islam masa ini di-dalam medan peperangan kehidupan?", al-Ikhwan, 2 (16 October, 1930).

105. Ibid.

106. Historians tend to focus on the presence of the British that destabilized the despotic nature of the feudal system by introducing the rule of law that limited the agency of the Malay kings. For the effects of colonial power to the Malay monarchy see: Mutalib, "Islamic Malay Polity in Southeast Asia"; Rupert Emerson, Malaysia: a Study of Direct and Indirect Rule (Kuala Lumpur: University of Malaya Press, 1969), 135 .

107. Gayatri Chakravorty Spivak, A Critique of Postcolonial Reason: toward a history of the vanishing present (Cambridge: Harvard University Press, 1999), 120.

108. Mat Ton, Politik al-Imam, 305.

109. Laffan, Islamic Nationhood and Colonial Indonesia ,148.

110. Zainon Ahmad, The Life, Times and Thoughts of Sayyid Syakh al-Hadi, 38.

111. Hourani, Arabic Thought in the Libcral Age, 396.

112. Al-Hady, "Teriak Sa-benar", al-Ikhwan I, 2 (16 October 1926).

113. Ibid.

114. Syed Shaykh al-Hady, Cetera Rokambul dengan Perbendaharaan Hindi atau Peperangan diantaraKebajikan dengan Kejahatan dalam Kehidupan Manusia [The story of Rokambul in India or the battle between good and evil in human's life] (Penang: Jelutong Press, date not known) 5, 11-20. See also: Jamilah Othman, Sayyid Shaykh al-Hadi, 71.

115. Al-Hady, "Teriak Sa-benar"; also: Syed Mohamed Alwi al-Ilady, "Syed Syakh: Through the Prism of a Child's Eyes \& the Al-Hady Clan," in The Real Cry of Syed Shaykh al-Hady, ed.Alijah Gordon (Kuala Lumpur: MSRI, 1999), 92.

116. Barbara Watson Andaya, "From Rum to Tokyo: The Search for Anticolonial Allies by the Rulers of Riau, 1899-1914" Indonesia 24 (1977), 123-56.

117. For information regarding the mutiny see: W. Bartley, "Singapore and the Great War" in One Hundred Years of Singapore, cds Makepcace, Brooke \& Braddell (Singapore: Oxford University Press, 1991), vol. 1, 408-9.

118. See: Abdullah Zakaria bin Ghazali, "Agama dan Kebangkitan Anti-British di Tanah Melayu," In Tamadun Islam di Malaysia, ed. Khoo Kay Kim (Kuala Lumpur: Persatuan Sejarah Malaysia, 1980), 124-34.

119. For the discussion on Daulat, see Michacl F. Laffan, "Dispersing God's shadows: Reflections on the translation of Arabic political concepts into Malay and Indonesian", paper written for the project "History of translations into Indonesian and Malaysian languages." Available [Onlinc]: <http://www.anu.edu.au/asianstudies/ahcen/proudfoot/ mmp/laffan_apc.html> [6 August 2004]. For the discussion on Nama and Derhaka see Milner, The Invention of Politics in Colonial Malaya, 10-30.

120. R.J. Wilkinson, Papers on Malay Subjects (Kuala Lumpur: Oxford University Press, 1971) 142.

121. Syed Shaykh al-IIadi, "Puji yang Sa-benar Makanan Nyawa Manusia", al-Ikhwan I, 8 (16 April 1927).

122. Syed Shaykh al-Hadi, "Ash-Sharaf: Kemuliaan atau Kehormatan", al-Imam II, 8 (4 February 1908).

123. Ibid. 
124. Syed Shaykh al-Hadi, Kitab Agama Islam dan Akal (Kota Bharu: Pustaka Dian, 1965), 33

125. Syed Hussain Alatas saw that the Malays were not guilty of indolence, yet there was a lack of the aggressive and acquisitive spirit of modern capitalism. Scc: Syed Hussain Alatas, The Myth of the Lazy Native: $A$ Study of the Image of the Malays, Filipinos, and Javanese from the Sixtecnth to the Twentieth Century and its Functions in the Ideology of Colonial Capitalism (London, Frank Cass, 1977), 213.

126. Maaruf, Malay ideas on Development, 63.

127. Syed Shaykh al-Hadi, Kitab Ugama Isfam dan Akal, 38-52. For an extensive discussion on the ideological and utopian naturc of al-Hady's thoughts, see: Syed Farid Alatas, "Ideology and Utopia in the thought of Syed Shaykh al-Hady, working paper, Department of Sociology (Singapore: National University of Singapore, 2005).

128. Maaruf, Malay Idcas on Development, 62.

129. Syed Ilussain Alatas The Myth of the Lazy Native, 213.

130. Ibid., 213-4.

131. Milner, The Invention of Politics, 236.

132. Syed Shaykh bin Ahmad al-Hady, Hikayat Faridah Hanom, 14.

133. Ibid. 6.

134. Ibid.. 135.

135. The tin output of Malaya in 1889 was about 26,000 tons and by 1905 it rose to 50,991 tons, roughly 54 percent of world output. The total tin carning from the Federated Malay States alone in 1907 was $\$ 78,000,000$ out of the total exports of $\$ 80,000,000$. The currency mentioned is in Straits dollars. In $1906, \$ 1.00=2$ Sterling and 1 ducat.

136. Li Dun-Jen, British Malaya, 38. The federation's revenue increased from $\$ 8,434,083$ in 1896 to a peak of $\$ 105,404,458$ in 1927.

137. W.I. Blythe, "Historical Sketch of Chinese Labour in Malaya", Journal of the Malayan Branch of the Royal Asiatic Socicty XX (1947): 64 .

138. Syed Shaykh al-Hady, "Menuntut Ketinggian Akan Anak-anak Negeri", al-Imam II, 1 (12 July 1907).

139. Ibid.

140. L.A. Mills, Malaya: A Political and Economic Appraisal (London: University of Minneapolis, 1958), 19.

141. C.F. Yong, \& R.B. McKenna, "Sir Arthur Young and Political Control of the Chinese in Malaya and Singapore, 1911-1919", Journal of the Malayan Branch of the Royal Asiatic Society 57,2 (1984), 1 .

142. Png Poh Seng, "The Kuomintang in Malaya, 1912-1941", Journal of South East Asian History 2, 2 (1961): 10.

143. Syed Shaykh al-Hadi, "Editorial", Saudara, (8 February 1933).

144. K. S. Sandhu, "Indian Immigration to Malaya", in Papers on Malayan History, ed. K.G. Tregonning (Singapore: Journal South-East Asian Ilistory, 1962) 40-73; $\triangle$ dapa Satyanarayana, "Birds of Passaga: Migration of South Indian labourers to Southeast Asia", Critical Asian Studies 34, 1 (2002): 89-115. The study of the ethnic Indian in Malay is still underdeveloped. To date, there are few scholars dealing with this issue. See for example: K.S. Sandhu and A. Mani, eds, Indian Communities in Southeast Asia (Singapore: ISEAS, 1993).

145. Syed Shaykh al-Ilady, "Kelantan Ulama" move to Ban al-lkhwan and Saudara". See also: Ibrahim Abu Bakar, "Al-Hadi's Political Thought", Hamdard Islamicus 18, 1, (1995): 102.

146. [Sungguhpun kami ini bukan daripada orang disini pihak keturunan tetapi daripada mereka itu pihak peranakan, istimewa pula telah kami sukakan negeri mereka itu watan bagi kami, Betapa tidak? Padahal sudah meminum kami akan air susunya dan tumbuh daripada daging darah kami] al-tmam 1, 1, (23 July 1906). See also Abdullah Basmih, "Almarhum Sayed Shaikh bin Ahmad al-Hadi Pujangga dan Pelopor Kesadaran Politik", Qalam (January 1958): 4. The English translation is from Michael F. Laffan, Dispersing God's Shadow. 
147. Anthony Reid, "Understanding Melayu", 295-313.

148. Ibid., 303.

149. Charles Hirschman, "The Making of Race in Colonial Malaya: Political Economy and Racial Ideology", Sociological Forum 1, 2 (1986) 341.

150. Michael F. Laffan, "Watan and Negeri: Mustafa Kamil's 'Rising Sun' in the Malay World", Indonesia Circle 69, (1996): 166.

151. Ibid., 167.

152. Sycd Shaykh al-Hady, "Sekolah Anglo-Malay", al-Ikhwan, IV 6 (16 Fcbruary 1930).

153. Anthony Milner, The Invention of Politics, 67. For a theoretical discussion on the relationship between map and national imagination see: Benedict Anderson, Imagined Communities, 170-8. For a study on the relationship between modern European geography and the change of perceptions on territory in Siam, sce: Thongchai Winichakul, Siam Mapped: A History of the Geo-body of a Nation (Honolulu: University of Hawaii Press, 1994). I am especially indebted to Panu Wongcha-Um for drawing my attention to the last book.

154. Utusan Melayu, 1907-1908.

155. Bassam Tibi, "Islam and Modern European Ideologies", 15-29.

156. A.H. Johns, "Sufism as a Category in Indonesian Literature and History", Joumal of Southeast Asian History 2, 2 (1961): 10-23. According to Peter Riddell, it was only in the late 19th century that the monopoly of theological works by the Sufis was challenged. Sec: Peter Ridell, Islam and the Malay-Indonesian WorId: Transmission and Responses (Singapore: Horizon Books, 2001), 208.

157. Syed Naquib al-Attas, Preliminary Statement on a General Theory of the Islamization of the Malay-Indonesian Archipclago (Kuala Lumpur: Dewan Bahasa dan Pustaka, 1969).

158. Syed Muhammad Naquib al-Attas, The Oldest Known Malay Manuscript: A 16th Century Malay Translation of the 'Aga'id of al-Nasati (Kuala Lumpur: University of Malaya Press, 1988).

159. Abu Hamid al-Ghazali, Thyaà' 'Uly̌m al-Dșn (Beirut: Dar al-Ma'rifah, 1980-1993) 4 Volumes.

160. Syed Naquib al-Attas, Some Aspects of Sufism as Understood and Practiced Among the Malays, ed. Shirle Gordon (Singapore: MSRI, 1963), 58.

161. For a Sufi refutation of modernism, see for instance a four volumes book written by the Mufti of Johor: Syed Alawi bin Tahir al-Haddad, Anwar al-Qur'an al-Mahiyyah al-Dzulumat Qadiyan (Johor Baharu: Jabatan Agama Johor, 1956).

162. Syed Shaykh al-Hady, :Membunoh Kaum Wahhabi Sunnat?", al-Ikhwan V, 10 (16 July 1931).

163. Syed Shaykh al-Hady, "Menuntut Ketinggian akan Anak-anak Negeri, al-Imam II, 1, (12 July 1907).

164. Frequently, the term magician is used, but 1 use sorcerer instead. Other possibilities are wizard, witch-doctor and soothsayers.

165. Richard Winstedt, The Malay Magician Bcing Shaman, Saiva and Sufi (Kuala Lumpur: Oxford University Press, 1982), 72.

166. Ibid., 81-102.

167. For an extensive survey on the Dutch fear of amulets, magic and Sufis in the Dutch Fast Indies, see Ahmad Baso, Islam Pasca-Kolonial: Pcrsclingkuhan Agama, Kolonialisme dan Liberalisme (Jakarta: Mizan, 2005), 183-218. See also Karel A. Steenbrink, "Kyai Nurhakim, Pemimpin Tarekat Khas Jawa: Tarekat Akmaliyah, Ahli Jimat dan Jampe" in Beberapa Aspek Tentang Islam di Indonesia Abad ke-19 (Jakarta: Bulan Bintang, 1984), 186-196.

168. Aqib Suminto, Politik Islam Hindia Bclanda: Kantor Urusan Agama Hindia Belanda (Jakarta: LP3ES, 1982), 70-8.

169. Syed Shaykh al-Hady, Kitab Ugama Islam dan Akal, 64; Ibrahim bin Abu Bakar, Islamic Modernism in Malaya, 78.

170. Syed Syaikh al-Hady, "Bukan Sa-kali-kali Agama Islam ini Sebab bagi Kejatuhan Kaum Islam tetapi Ilanya -lah sebab Angkara Ketua-Ketua Agama", al-Ikhwan V, 3 (16 November 1930). 
171. Ibid.

172. Ibid

173. For details of the first civil war, see the work of the great classical Muslim chronicler, At-Tabari: At-Tabari, Tarikh al-Rusul wa al-Mulk, translated and annotated by G.R. Hawting (Albany: State University of New York Press, 1996) vol. 17.

174. Syed Shaykh al-Hady, Kitab Alam Pcrempuan, 26.

175. See for instance; Sir Hugh Clifford, In a Comer of Asia: Bcing Tales and Impressions of Men and Things in the Malay Pcninsula (London: T, Fisher Unwin, 1925); Sir Hugh Clifford, A Prince of Malaya (New York: Harper, 1926).

176. Ashis Nandy, The Intimate Enemy: Loss and Recovery of Solf Under Colonialism (Delhi: Oxford University Press, 1983), 88.

177. Ibrahim bin Abu Bakar, islamic Modernism, 110.

178. Syed Naquib al-Attas, Some Aspects of Sufism, 38.

179. Syed Shaykh al-Hady, "Lebaik Pondok", al-lkhwan II, 6 (16 February 1928).

180. Ibid.

181. Syed Shaykh al-Hady, "Editorial", Saudara (24 February 1933).

182. Ibid.

183. Zainal-Abidin B. Ahmad, "Malay Journalism in Malaya", Journal of the Malayan Branch of the Royal Asiatic Socicty XIX, II, (1941), 244-50.

184. Ibid.

185. Virginia Matheson Hooker, Writing A New Socicty: Social Change Through the Novel in Malay (IIonolulu \& Sydney: Allen \& Unwin and University of Hawaii Press, $2000), 24$.

186. On the difficulty of gauging audience response, see: Susan Douglas, "Notes towards a Writing of Media Audiences," Radical History Review 54 (1992).

187. Ibrahim bin Abu Bakar, Islamic Modernism, 121.

188. Linda Tan, "The Life and Times", 160.

189. Syed Shaykh al-Hady, "Sckolah Anglo-Malay", al-Ikhwan IV, 6 (16 Fcbruary 1930).

190. Thid.

191. Thomas Macaulay, "Minute on Indian Education", in The Post-Colonial Studies Rcader, eds Bill Ashcroft et. al (London: Routledge, 1995), 430.

192. Gauri Viswanathan, "The Beginning of English Literary Study in British India", in The Post-Colonial Studics Reader, eds Bill Ashcroft et. al (London: Routledge, 1995), 434.

193. Antonio Gramsci, Selections from the Prison Notebooks of Antonio Gramsci, eds Quintin Hoare \& Geoffrcy Nowell Smith (I.ondon: Lawrence \& Wishart, 1971), 57.

194. Frederick Cooper \& Ann Laura Stoler, "Between Metropole and Colony: Rethinking a Research Agenda", in Tensions of Empire: Colonial Cultures in a Bourgeois World, eds lirederick Cooper \& Ann Laura Stoler (Berkeley: University of California Press, 1997), 1-56.

195. Syed Syakh al-Hady, "Ada-kah Kaum Melayu ini Dapat Melepaskan Wujud-nya daripada Fana dan Hapus? Adakah Penyakit ketewasan semua kaum Islam masa ini di-dalam medan peperangan kehidupan?", al-1khwan V, 2 (16 October, 1930).

196. Anthony Milner. The Invention of Politics, 98; William Roff, The Origins of Malay Nationalism, 159.

197. Anthony Milner, The Invention of Politics, 92-3.

198. Ibid., 98. See also: Ariffin Omar, Bangsa Melayu: Malay Concepts of Democracy and Community 1945-1950 (Kuala Lumpur: Oxford University Press, 1993), 16.

199. Ariffin Omar, Bangsa Melayu, 16.

200. Syed Shaikh al-Hady, "Persekutuan Anak-anak Alam Mclayu", al-Ikhwan I, 1 (16 September 1926).

201. Ariffin Omar, Bangsa Melayu, 17.

202. Ibid., 45 .

203. Ibid., 100 .

204. Frantz Fanon, The Wretched of the Earth (London: Penguin Classics, 2001), 36.

205. T.N. Harper, The End of Empire and the Making of Malaya (Cambridge: Cambridge University Press, 1967), 362. 
206. For the recurrent problems of ethnic tensions and communalism, see: Fred R. von der Mehden, "Malaysia: Islam and Multiethnic Politics", in Islam in Asia: Religion, Politics and Society, ed. John L. Esposito (Oxford: Oxford University Press, 1987); Judith Nagata, "Religious Ideology and Social Change: The Islamic Revival in Malaysia", Pacific Affairs 53, 3 (1980): 405-39.

207. J. Farish, "Minute dates August 28th 1838, Political Dept, Vol. $20 / 795$ (Bombay Records)"; quoted in B.K. Boman-Behram, Educational Controversies of India: The Cultural Conquest of India under British Imperialism (Bombay: Taraporevala Sons, 1942), 239.

208. William. R. Roff, The Origins of Malay Nationalism, 57

209. Radin Socnarno, "Malay Nationalism 1896-1941", The Journal of South East Asian History, 1 (1960) 6-7.

210. Fazlur Rahman, "Islamic Modernism: Its Scope, Method and Alternatives", 323.

211. J. Farish, "Minute dates August 28th 1838, Political Dept, Vol. 20/795 (Bombay Records)"; quoted in B.K. Boman-Behram, Educational Controversies of India, 243.

212. Sec for instance: Joseph E.B. Lumbard, ed., Islam, Fundamentalism, and the Betrayal of Tradition: Essay by Western Muslim Scholars; Mansoor Moaddel, Islamic Modernism, Nationalism and Fundamentalism: Episode and Discourse (Chicago: University of Chicago Press, 2005); Tariq Ali, The Clash of Fundanentalism: Crusade, Jihads and Modernity (London: Verso, 2003).

213. For the case of the Liberal Islamic Network (JIL) in Indonesia, see: Hartono Ahmad Jaiz, Menangkal Bahaya JIL dan FLA (Jakarta: Pustaka al-Kautsar, 2003); Luthfi Assyaukanie, ed., Wajah Libcral Islam di Indonesia (Jakarta: Jaringan Islam Liberal, 2002).

214. William Shakespeare, The Tempest (London: Penguin Books, 1996) 1.2, 77. 


\section{Bibliography}

Primary Sources:

al-Attas, Syed Muhammad Naquib. The Oldest Known Malay Manuscript: $A 16^{\text {th }}$ Century Malay Translation of the 'Aqa'id of A1-Nasafi. Kuala Lumpur: University of Malaya Press, 1988.

al-Ghazali, Abu Hamid. Ihya' 'Ulum al-Din. Beirut: Dar al-Ma'rifah, 1993.

al-Haddad, Syed Alawi bin Tahir. Anwar al-Qur'an al-Mahiyyah al-Dzulumat Qadiyan. Johor Baharu: Jabatan Agama Johor, 1956.

al-Hady, Syed Alwi. "The life of my Father". In The Real Cry of Syed Shaykh al-Hady, edited by Alijah Gordon, 57-84. Kuala Lumpur: MSRI, 1999.

Al-Hady, Syed Muhammad Alwi. Syed Syakh: Through the Prism of a Child's Eyes \& the Al-Hady Clan". In The Real Cry of Syed Shaykh al-Hady, edited by Alijah Gordon, 85108. Kuala Lumpur: MSRI, 1999.

al-Hady, Syed Shaykh. Cetera Rokambul dengan Perbendaharaan Hindi atau Peperangan diantara Kebajikan dengan Kejahatan dalam Kchidupan Manusia. Penang: Jclutong Press, n.d.

- Al-Tarikh al-Islami. Pulai Pinang: Marcantile Press, 1922.

- Hikayat Faridah Hanom. Kuala Lumpur: Pustaka Antara, 1964.

Hikayat Puteri Nurul Ain. Pulau Pinang: Jelutong Press, 1928.

- Hikayat Taman Cinta Berahi. Pulau Pinang: Jelutong Press, 1927.

Kitab Alam Perempuan. Pulau Pinang: Jelutong Press, 1930.

Kitab Ugama Islam dan 'Akal. Kota Bharu: Pustaka Dian, 1965.

Tafsir al-Fatihah. Pulau Pinang: Jelutong Press, 1928.

al-Jurjani, Ali bin Muhammad. Kitab at-Ta'rifat. Cairo: Dar al-Irshad, 1991.

Assyathiri, Sayid Muhammad Ahmad. Sirah as-Salaf min Bani 'Alawiy Al-Husainiyin. Jeddah: 'Alam al-Ma'rifah, $\Lambda \mathrm{H} 1405$.

At-Tabari. Tarikh al-Rusul wa al-Mulk. Translated and annotated by G.R. Hawting. (Albany: State University of New York Press, 1996.

Clifford, Sir Hugh. In a Corner of Asia: Being Tales and Impressions of Men and Things in the Malay Peninsula. London: T. Fisher Unwin, 1925.

- A Prince of Malaya. New York: Harper, 1926.

Holy Qur'an. Translated by A. Yusuf Ali. N.P.: Islamic Propagation Centre International, 1946.

Ibn Mandzur. Lisan al-'Arab. Beirut: Dar al-Ihya' wa al-Turath al-Arabi, 1997.

Lanc, Fdward William. Arabic-English Lexicon. New York: Frederick Ungar Publishing, 1956.

Macaulay, Thomas. "Minute on Indian Education." In The Post-Colonial Studies Reader, edited by Bill Ashcront, Gareth Griffiths and Helen Tiffin, 428-30. London: Routledge, 1995.

Renan, Ernest. "What is a Nation?" In Becoming National: $A$ Roader, edited by Geofl Elcy \& Ronald Grigor Suny, 41-55. New York: Oxford University Press, 1996.

Wilkinson, R.J. Papers on Malay Subjects, Kuala Lumpur: Oxford University Press, 1971.

Winstedt, R. O. "A History of Malay Literature." Journal of the Malayan Branch of the Royal Asiatic Society, 17, 3 (1939): 1-243.

- The Malays: A Cultural History. London: Routledge \& Kegan Paul, 1961

The Malay Magician Being Shaman, Saiva and Sufi. Kuala Lumpur: Oxford University Press, 1982.

Ya'qub, Abu Yusuf. Kitab al-Kharaj. Beirut: Dar al-Ma'rifah, 1979.

Periodicals:

Al-lkhwan, 1926-1931.

Al-Imam, 1905-1908.

Saudara, 1928-1935.

Utusan Melayu, 1907-1908. 
Secondary Sources:

Abaza, Mona. Islamic Education: Perception and Exchanges, Indonesian Students in Cairo. Paris: Association Archipel, 1994.

Abdul Aziz, Sohaimi. "Pengenalan." In Syed Syeikh al-Hadi: Cendekia dan Sasterawan Ulung, edited by Sohaimi Abdul Aziz, 1-8. Pulau Pinang: Penerbit Universiti Sains Malaysia, 2003.

- Islamic Modernism in Malaya: The Life and Thought of Sayid Syekh al-Hadi, 18671934. Kuala Lumpur: University of Malaya Press, 1994.

Ahmad Jaiz, Hartono. Menangkal Bahaya JIL dan FLA. Jakarta: Pustaka al-Kautsar, 2003. Ahmad, Zainon. "The Life, Times and Thoughts of Sayyid Shaykh al-Hadi." M.A. Thesis, University of Malaya, 1979.

al-Ahsan, Abdullah. Ummah or Nation? Identity Crisis in Contemporary Muslim Society. Leicester: The Islamic Foundation, 1992.

Alatas, Syed Farid. "Ideology and Utopia in the thought of Syed Shaykh al-Hady". Working paper, Department of Sociology (Singapore: National University of Singapore, 2005).

Alatas, Syed Hussain. The Myth of the Lazy Native: A Study of the Image of the Malays, Fifipinos, and Javanese from the Sixteenth to the Twentieth Century and its Functions in the Idcology of Colonial Capitalism. London, Frank Cass, 1977.

_ "Academic Imperialism." In Reflection on Alternative Discourse from Southeast Asia: Proceedings of the ISA Regional Conference for Southeast Asia, Singapore 30 May-1 June 1998, edited by Sycd Farid Alatas, 32-46. Singapore: Pagesetters Service, 2001.

al-Attas, S. M. Naquib. Some Aspects of Sufism as Understood and Practiced Among the Malays, edited by Shirle Gordon. Singapore: MSRI, 1963.

- Preliminary Statement on a General Theory of the Islamization of the Malay. Indoncsian Archipelago. Kuala Lumpur: Dewan Bahasa dan Pustaka, 1969.

_- "Appendix: On Islamization: The Case of the Malay-Indonesian Archipelago" in Islam and Secularism. Kuala Lumpur: ISI AC, 1993.

— Islam and Secularism. Kuala Lumpur: ISTAC, 1993.

al-Husry, Khaldun S. Three Reformers, A Study in Modern Arab Political Thought. Beirut: Khayats, 1966.

Ali, Tariq. The Clash of Fundamentalism: Crusade, Jihads and Modemity. London: Verso, 2003.

Andaya, Barbara Watson. "From Rum to Tokyo: The Search for Anticolonial Allies by the Rulers of Riau, 1899-1914" Indoncsia, 24 (1977): 123-56.

Anderson, Benedict. Imagined Communities: Reflections on the Origin and Spread of Nationalism. London: Verso, 1991.

Apter, David F. The Politics of Modernization. Chicago: University of Chicago Press, 1965.

Armstrong, Karen, Islam: A Short History. London: Phoenix Press, 2000.

Asad, Muhammad. The Message of the Quran. Gibraltar: Dar al-Andalus, 1980.

Asad, Talal, Formations of the Secular: Christianity, Islam and Modernity. Stanford: Stanford University Press, 2003.

Assyaukanie, Luthfi (ed.). Wajah Liberal Islam di Indonesia, Jakarta: Jaringan Islam Libcral, 2002.

Azra, Azrumardi. The origins of Islamic reformism in Southeast Asia :Nnetworks of Malay-Indonesian and Middle Eastern 'Ulamảa" in the Seventeenth and Eightecnth Centuries. Crows Nest : Allen \& Unwin, 2004.

Badawi, M.A. Zaki. The Reformers of Egypt. London: Croom Helm, 1978.

Bartley, W. "Singapore and the Great War." In Onc Hundred Years of Singapore, edited by W. Makepeace, G.E. R St J.Brooke \& Braddell. Singapore: Oxford University Press, 1991.

Basmih, Abdullah. "Almarhum Sayed Shaikh bin Ahmad al-Hadi Pujangga dan Pelopor Kesadaran Politik." Qalam (January 1958): 3-7. 
Baso, Ahmad. Islam Pasca-Kolonial: Perselingkuhan Agama, Kolonialisme dan Libcralisme. Jakarta: Mizan, 2005:183-218.

Bhabha, Homi. The Location of Culture, London: Routledge, 1994.

— "Of Mimicry and Man: The Ambivalence of Colonial Discourse." In Tension of Empire: Colonial Cultures in a Bourgeois World, edited by Frederick Cooper \& Ann Laura Stoler, 152-160. Berkeley: University of California Press, 1997.

Black, Antony. The History of Islamic Political Thought: From the Prophet to the Present. Edinburgh: Edinburgh University Press, 2001.

Bluhm, Jutta E. "Preliminary Statement on the Dialogue Established Between the Reform Magazine al-Manar and the Melayo-Indonesian World." Indonesian Circle 32 (1983): $35-42$.

Blythe, W.L. "Historical Sketch of Chinese Labour in Malaya." Journal of the Malayan Branch of the Royal Asiatic Socicty XX (1947): $57-73$

Boman-Behram, B.K. Educational Controversies of India: The Cultural Conquest of India under British Imperialism. Bombay: 'Taraporevala Sons, 1942.

Chaterjee, Partha. Nationalist Thought and the Colonial World: A Derivative Discourse? New Delhi: Zed Books, 1985.

Cleveland, William L. A History of the Modern Middle East, second edition. Boulder: Westview Press, 2000.

Cooper, Frederick \& Stoler, Ann Laura. "Between Mctropole and Colony: Rethinking a Research Agenda." In Tensions of Empire: Colonial Cultures in a Bourgeois World, edited by Frederick Cooper \& Ann Laura Stoler, 1-56. Berkeley: University of California Press, 1997.

Cox, Harvey. The Secular City. London: SCM Press, 1966.

Cragg, Kenneth. "Religious Development in Islam in the $20^{\text {di }}$ Century." Cahiers d'Histoirc Mondiale 3, 2 (1974): 504-524.

Devereux, Robert. The First Ottoman Constitutional Period; $\Lambda$ Study of the Midhat Constitution and Parliament. Baltimore: Johns Hopkins, 1963.

Douglas, Susan. "Notes towards a History of Media Audiences." Radical History Review 54 (1992): 105-123

Duri, A.A. The Historical Formation of the Arab Nation. Translated by Lawrence I. Conrad. London: Croom Helm, 1987.

Emerson, Rupert. Malaysia: A Study of Direct and Indirect Rule. Kuala Lumpur: University of Malaya Press, 1969.

Fanon, Frantz. The Wretched of the Earth. London: Penguin Classics, 2001.

Ghazali, Abdullah Zakaria bin. "Agama dan Kebangkitan Anti-British di Tanah Melayu." In Tamadun Islam di Malaysia, edited by Khoo Kay Kim, 124-34. Kuala Lumpur: Persatuan Sejarah Malaysia, 1980.

Gucek. Fatma M. The Rise of the Bourgeoisie, Demise of Empire - Ottoman: Westernisation and Social Change. Oxford: Oxford University Press, 1996.

Gramsci, Antonio. Selections from the Prison Notebooks of Antonio Gramsci, edited by Quintin Hoare \& Geoffrey Nowell Smith. London: Lawrence \& Wishart, 1971.

Haddad, Yvonne, "Muhammad 'Abduh: Pioneer of Islamic Reform" In Pioncers of Islamic Revival, edited by Ali Rahnama, 30-63. London: Zed Books, 1994.

Haji Yahaya, Mahayudin. "Latarbelakang Sejarah Keturunan Sayid di Malaysia." In Tamadun Di Malaysia, edited by Khoo Kay Kim, 60-73. Kuala Lumpur: Persatuan Sejarah Malaysia, 1980.

Hamzah, Abu Bakar. "Sheikh Tahir Jalalu'ddin", Medium 1 (1988): 88-95.

Harper, T.N. The End of Empire and the Making of Malaya. Cambridge: Cambridge University Press, 1967.

Heyworth-Dunne, J. "Rifa'a Bey Rafi' al-Tahtawi." Bulletin of the School of Oriental and African Studies IX (1937/39): 961-7.

Hirschman, Charles. "The Making of Race in Colonial Malaya: Political Economy and Racial Ideology." Sociological Forum 1, 2 (1986): 330-61.

Hitti, Philip K. History of the Arabs. Jakarta: Serambi, 2005. 
Hooker, Virginia Matheson, Writing A New Society: Social Change Through the Novel in Malay. Honolulu \& Sydney: Allen \& Unwin and University of Hawaii Press, 2000.

Hourani, Albert. Arabic Thought in the Liberal Age. Translated by Suparno. Bandung: Mizan, 2004.

Hussain, Abdullah \& Hussain, Khalid. Pendita Zaaba Dalam Kenangan. Kuala Lumpur: Dewan Bahasa dan Pustaka, 1974.

Johns, A.H. "Sufism as a Category in Indonesian Literature and History." Journal of Southeast Asian History 2, 2 (1961): 10-23.

Keddie, Nikki R. "Pan-Islam as Proto-Nationalism." The Journal of Modern History 41, I (1969): 17-28.

- An Islamic Response to Imperialism: Political and Religious Writings of Sayyid Jamal al-Din al-Afghani. Berkeley: University of California Press, 1983.

Kedourie, Elie. Afghani and 'Abduh: An Essay on Religious Unbelief and Political Activism in Modern Islam. London: Frank Cass, 1966.

Khoo Kay Kim, "Malay Socicty, 1874-1920s," Journal of Southeast Asian Studies V, 2 (1974):179-98.

Kurzman, Charles. "Introduction: Liberal Islam and Its Islamic Context". In Liberal Islam: A Sourcebook, edited by Charles Kurzman, 3-26. Oxford: Oxford University Press, 1998.

Laffan, Michael F. "Watan and Negeri: Mustafa Kamil's 'Rising Sun' in the Malay World." Indonesia Circle, 69, (1996): 156-175.

- Islamic Nationhood in Colonial Indonesia: The Umma Below the Winds. London: RoutledgeCurzon, 2003.

— "Dispersing God's shadows: Reffections on the translation of Arabic political concepts into Malay and Indonesian", paper written for the project "History of translations into Indonesian and Malaysian languages." Available [Online]: Lhttp:// www.anu.cdu.au/asianstudics/ahcen/proudfoot/mmp/laffan_apc.htm/ $>$ [6 August 2004].

Lewis, Bcrnard. The Emergence of Modern Turkey. London: Oxford University Press, 1961.

— "Watan." Journal of Contemporary History 26, 3/4 (1991): 523-33.

Li Dun-Jen. British Malaya, An Economic Appraisal. New York: The American Press, 1955.

Lumbard, Joseph E.B, (cds). Islam, Fundamentalism, and the Betrayal of Tradition: Essay by Western Muslim Scholars. Bloomington, IN: World Wisdom, 2004.

Maaruf, Shaharuddin. Malay Ideas on Development: From Feudal Lord to Capitalist. Singapore: Times Book International, 1988.

Mardin, Serif. The Genesis of Young Ottoman Thought: A Study in the Modernization of Turkish Political Ideas. Syracuse: Syracuse University Press, 2000.

Mat Ton, Abdul Aziz. Politik al-Imam. Kuala Lumpur: Dewan Bahasa \& Pustaka, 2001.

Menemencioglu, Nermin. "The Ottoman Theatre, 1839-1923." Bulletin 10, 1 (1983): 48-58.

Mills, L.A. Malaya: A Political and Economic Appraisal. London: University of Minneapolis, 1958.

Milner, A.C. Kerajaan: Malay Politcal Culture on the Eve of Colonial Rule. Tucson: University of Arizona Press, 1982.

- The Invention of Politics in Colonial Malaya. Cambridge: Cambridge University Press, 2002.

Moaddel, Mansoor. Islamic Modernism, Nationalism and Fundamentalism: Episode and Discourse. Chicago: University of Chicago Press, 2005.

Mohd. Nor Bin Ngah. "Islamic World-view of Man, Society and Nature among the Malays." In Malaysian World-View, edited by Mohd. Taib Osman. Singapore: Institute of $\Lambda$ sian Studies, 1985.

Morley, J. A. E. "The Arabs and the Eastern Trade." JMBRAS 22, 1 (1949): 143-76.

Mutalib, Hussin. "Islamic Malay Polity in Southeast Asia," In Islamic Civilization in the Malay World, edited by Mohd. Taib Osman. Kuala Lumpur: Dewan Bahasa dan Pustaka, 1997. 
Nagata, Judith. "Religious Ideology and Social Change: The Islamic Revival in Malaysia." Pacific Affairs 53, 3 (1980): 405-39.

Nandy, Ashis. The Intimate Encmy: Loss and Recovery of Self Under Colonialism. Delhi: Oxford University Press, 1983.

Nasr, Seyyed Hossein. Islam: Religion, History and Civilization. Surabaya: Risalah Gusti, 2003.

Omar, Ariffin. Bangsa Melayu: Malay Concepts of Democracy and Community 19451950. Kuala Lumpur: Oxford University Press, 1993.

Othman, Jamilah. "Sayyid Syakh al-Hadi- His Role in the Transformation of Muslim Societies in Peninsular Malaya and the Straits Settlements during the Latter Half of the Nineteenth and Early Twentieth Centuries." M.A. Thesis, University of Malaya, 1979.

Png Poh Seng, "The Kuomintang in Malaya, 1912-1941." Journal of South East Asian History 2, 2 (1961): 1-41.

Rahman, Fazlur, "Islamic Modernism: Its Scope, Method and Alternatives." In International Journal of Middle East Studies I, 4 (1970): 317-33.

Reid, Anthony. "Understanding Melayu (Malay) as a source of diverse modern identities." Journal of Southeast Asian Studies 32, 3 (2001): 295-313.

Ridell, Peter. Islam and the Malay-Indonesian World: Transmission and Responses. Singapore: Horizon Books, 2001.

Roff, William. The Origin of Malay Nationalism. Kuala Lumpur: University of Malaya Press, 1967.

_ "Indonesian and Malay Students in Cairo in the 1920s." Indonesia 9 (1970): 73-87.

- Bibliography of Malay and Arabic Pcriodicals Published in the Strait Settlements and Peninsular Malay States 1876-1941. London: Oxford University Press, 1972.

Saffran, Nadav. Egypt in Search of Political Community: An Analysis of the Intellectual and Political Evolution of Egypt, 1804-1952. Cambridge: Harvard University Press, 1981.

Sandhu, K.S. \& Mani, A (cds). Indian Communities in Southeast Asia. Singapore: ISEAS, 1993.

Sandhu, Kernial Singh. "Indian Immigration to Malaya." In Papers on Malayan History, edited by K.G. Tregonning, 40-73. Singapore: Journal South-East Asian History, 1962.

Sawaie, Mohammed. "Rifa"A Rafi Al-Tahtawi and his contribution to the lexical development of modern literary Arabic." International Journal of Middle East Studies 43, 3 (2000): 395-410.

Shakespeare, William. The Tempest. London: Penguin Books, 1996.

Sham, Abu Hassan. "Tariqat Naqsyabandiyah dan Peranannya dalam Kerajaan Melayu Riau sehingga Awal Abad Kedua Puluh." In Tamadun Islam di Malaysia, edited by Khoo Kay Kim, 74-86. Kuala Lumpur: Persatuan Sejarah Malaysia, 1980.

Sharabi, Hisham, Arab Intellectuals and the West: the Formative Year, 1875-1914. Baltimore: Johns Hopkins Press, 1970.

Shils, Fdward. The Intellectuals and the Powers and Other Essays. Chicago: University of Chicago Press, 1972

Socnarno, Radin. "Malay Nationalism, 1896-1941." The Journal of South East Asian History I (1960): 1-28.

Spivak, Gayatri Chakraworty. A Critique of Postcolonial Reason: toward a history of the vanishing present. Cambridge: Harvard University Press, 1999.

Steenbrink, Karcl A. Beberapa Aspek Tentang Islam di Indonesia Abad ke-19. Jakarta: Bulan Bintang, 1984.

Suminto, H. Aqib. Politik Islam Hindia Belanda: Kantor Urusan Agama Hindia Belanda. Jakarta: LP3ES, 1982.

Taib Osman, Mohd. "The Traditional Malay Socio-Political World-View." In Malaysian World-View, edited by Mohd.Taib Osman. Singapore: Institute of Asian Studies, 1985.

Tamimi, Azzam S. "The Renaissance of Islam." Dedalus 132, 3 (2003): 51-8.

Tan, Linda. "Syed Shaykh: His Life and Times." In The Real Cry of Syed Shaykh al-Hady, edited by Alijah Gordon, 109- 62. Kuala Lupur: MSRI, 1999. 
Tibawi, A.L. Arabic and Islamic Themes: Historical, Educational and Literary Studies. London: Luzac \& Company, 1976.

Tibi, Bassam. "Islam and Modern European Ideologies." International Journal of Middle East Studies 18, 1 (1986): 15-29.

Arab Nationalism: A Critical Inquiry, second edition. London: Macmillan, 1990.

Viswanathan, Gauri. "The Beginning of English Literary Study in British India." In The Post-Colonial Studies Reader, edited by Bill Asheroft, Gareth Griffiths and Helen Tiffin, 431-7. London: Routledge, 1995.

Von der Mehden, Fred R. "Malaysia: Islam and Multiethnic Politics." In Islam in Asia: Religion, Politics and Socicty, edited by John L. Esposito. Oxford: Oxford University Press, 1987.

Wendell, Charles. The Evolution of the Egyptian National Image: From Its Origins to Ahmad Lutfi al-Sayyid. Berkeley: University of California Press, 1972.

Winichakul, Thongchai. Siam Mapped: A History of the Geo-body of a Nation. Honolulu: University of Hawaii Press, 1994.

Yong, C.F. \& McKenna, R.B. "Sir Arthur Young and Political Control of the Chinese in Malaya and Singapore, 1911-1919." Journal of the Malayan Branch of the Royal Asiatic Society 57, 2 (1984): 1-23.

Zainal-Abidin B. Ahmad. "Malay Journalism in Malaya." Journal of the Malayan Branch of the Royal Asiatic Society XIX, 11, (1941): 244-50.

- "The Malays and Religion." In Tamadun Islam di Malaysia, edited by Khoo Kay Kim, 103-12. Kuala I.umpur: Persatuan Sejarah Malaysia, 1980.

Ismail F. Alatas received his Bachelor of Arts with Honours majoring in history from the University of Melbournc, Australia. 